\title{
Bioeconomy perception by future stakeholders: Hearing from European forestry students
}

\author{
Mauro Masiero (1), Laura Secco, Davide Pettenella, Riccardo Da Re, \\ Hanna Bernö, Ariane Carreira, Alexander Dobrovolsky, Blanka Giertlieova, \\ Alexandru Giurca, Sara Holmgren, Cecilia Mark-Herbert, Lenka Navrátilová, \\ Helga Pülzl, Lea Ranacher, Alessandra Salvalaggio, Arnaud Sergent, \\ Juuso Sopanen, Cristoph Stelzer, Theresa Stetter, Lauri Valsta, \\ Jozef Výbošt'ok, Ida Wallin
}

Received: 23 December 2019/Revised: 10 June 2020/Accepted: 31 July 2020/Published online: 13 October 2020

\begin{abstract}
This article provides useful information for universities offering forestry programs and facing the growing demand for bioeconomy education. An explorative survey on bioeconomy perception among 1400 students enrolled in 29 universities across nine European countries offering forestry programs was performed. The data have been elaborated via descriptive statistics and cluster analysis. Around $70 \%$ of respondents have heard about the bioeconomy, mainly through university courses. Students perceive forestry as the most important sector for bioeconomy; however, the extent of perceived importance of forestry varies between countries, most significantly across groups of countries along a North-South European axis. Although differences across bachelor and master programs are less pronounced, they shed light on how bioeconomy is addressed by university programs and the level of student satisfaction with this. These differences and particularities are relevant for potential development routes towards comprehensive bioeconomy curricula at European forestry universities with a forestry focus.
\end{abstract}

Keywords Bioeconomy · Education ·

Forest-based bioeconomy · Forestry students .

Future stakeholders $\cdot$ Perception

\section{INTRODUCTION}

The transition to a bioeconomy can take many forms and will need wide social as well as political-institutional

Electronic supplementary material The online version of this article (https://doi.org/10.1007/s13280-020-01376-y) contains supplementary material, which is available to authorized users. changes shaping possible future action (Goven and Pavone 2015) while requiring transformational efforts (Dietz et al. 2018; Lewandowski 2018). In order to face such changes and transformations, and to avoid that bioeconomy remains an "elite master narrative [...that...] does not depend on popular acceptance, acquiescence and even awareness" (Birch et al. 2010, p. 2905), public opinions and social preferences shall be taken into account. For involving stakeholders at a societal level in discussions and decisionmaking processes, their perceptions about matters that directly affect their well-being need to be investigated (Mustalahti 2017). While a number of studies were conducted on bioeconomy, bio-based products, and associated technologies, research has only recently started to focus on interactions between actors involved in a bioeconomy (Hodge et al. 2017; Lewandowski 2018; Stein et al. 2018) and about the role of society in shaping and co-creating bioeconomy (Ramcilovic-Suominen and Pülzl 2018; Golowko et al. 2019; Sanz-Hernández et al. 2019).

Among future stakeholders, university students will be centre-stage for the development and implementation of a bioeconomy as future decision makers and a key future workforce shaping and enabling it. Already now the bioeconomy employs $8.2 \%$ of the European Union (EU) labour force (EC 2019), and is expected to stimulate new types of job opportunities, particularly within the forest-based sector, while the number of traditional forestry-related jobs continues to decrease (UNECE/FAO 2018). The potential to generate new (green) jobs through bioeconomy, however, also depends on universities' ability to answer the demand for the interdisciplinary skills and specifically educated professionals needed for an innovative bioeconomy (Lewandowski 2018; UNECE/FAO 2018). In addition, educators have raised concerns over the everincreasing shortage of talented workforce needed to realize 
ambitious bioeconomy goals. For example, Hakovirta and Lucia (2019) claim that the bioeconomy needs to attract youth to science, technology, engineering and mathematics disciplines while cultivating the multidisciplinary skills needed for a future workforce. The enhancement and updating of educational programs and learning initiatives were pointed out as important aspects for enabling bioeconomy and the associated societal transition (Lewandowski 2018; Golowko et al. 2019). In this regard, Higher Education Institutions (HEI) play central role as they are a prerequisite for transformational efforts by increasing competencies and facilitating transition via transparent, participative processes and a close dialogue across multiple disciplines (Herget 2018).

So far, few studies addressed students' perception of bioeconomy (e.g. Drejerska 2017; Hempel et al. 2018; Stern et al. 2018a, b). Student-specific as well as crosscountry comparative studies are rare (Mastalka and Timonen 2017; Golowko et al. 2019) and consider students' perception from very specific angles (e.g. Pätäri et al. 2017). The research gap on bioeconomy perception among students is even more evident when focusing on forest-based bioeconomy (FBB) i.e. the segment of bioeconomy depending on forest resources as material/service providers for a transition to an alternative economic model (Scarlat et al. 2015). The "bioeconomy is expected to be the guiding paradigm within the forest-based sector in the years to come" (Wolfslehner et al. 2016, p. 5). Therefore, this explorative study aims to fill this research gap by investigating and comparing the current perceptions of bioeconomy by forestry students in different parts of Europe. In doing so, the following research questions are addressed:

1. To what degree have forestry students heard about bioeconomy and what are their sources of information?

2. How forestry students enrolled in different programs across different countries in Europe perceive bioeconomy and FBB? In particular:

2.1 How do students perceive their information and training regarding bioeconomy at university?

2.2 How do forestry students perceive the role of the forest sector within the bioeconomy today, both at the European and the national scale?

2.3 What are the current and future FBB development drivers/orientations and possible impacts students perceive?

By addressing these questions, the paper aims to provide exploratory information that might be helpful for universities offering forestry-related programs interested to consider adapting and expanding their curricula. At the same time, by highlighting current bioeconomy perceptions of key future stakeholders, and analyse them comparatively, it aims to identify possible educational development trajectories that can be considered by policy and decision makers at both the national and European level.

The next section of the paper describes materials and methods employed, as well as the scope of the study. Results are presented in section three and discussed in section four. Finally, section five draws conclusions, highlighting the main findings, limitations and further research needs.

\section{MATERIALS AND METHODS}

An explorative multi-language online questionnaire (Appendix S1) was developed targeted at Bachelor (BSc), Master (MSc) and Doctorate $(\mathrm{PhD})$ students currently enrolled in forestry programs across Europe. Student programs were selected to cover all distinct European regions: Northern (Finland-FIN and Sweden-SWE), Central-Western (Austria-AUT, Germany-GER, France-FRA), Southern (Italy-ITA and Spain-ESP) and Eastern Europe (Slovakia-SVK and the Russian Federation-RUS). One or more top-ranked forestry universities from each country were selected for the survey. The opportunities for a FBB differ across the European continent (Hurmekoski et al. 2019) and therefore the selection of target countries is designed to capture this variation as they are also at different stages in their bioeconomy policy development. For example, GER and FIN have dedicated national bioeconomy strategies since a longer time period as compared to FRA, ITA and ESP. AUT published its strategy only in 2019, while SVK has just developed one and SWE and RUS have other bioeconomy-relevant policy initiatives in place.

The questionnaire was made available in a default English version as well as national languages. It consisted of open, close-ended, multiple choice and rating-scale questions organized into six sections. The present study focuses on the following three however:

1. "Familiarity with bioeconomy" investigated how familiar students are with the bioeconomy concept and related strategies at both European and national scale. Respondents were not given a definition of bioeconomy at this stage, as one of the aims of the survey was to investigate 'blind' knowledge and their perception.

2. "Bioeconomy at university" investigated to what extent and in which courses bioeconomy was addressed within university forestry programs. At the beginning of this section, the European Commission 
(EC 2012, 2018) definition for bioeconomy was provided.

3. "Activities, issues, sectors, and actors associated to bioeconomy" aimed at identifying students' bioeconomy perception for Europe and the country they were studying in as well as expected bioeconomy barriers, divers and impacts. Special attention was paid to FBB and the role of the forest sector within bioeconomy.

The study relied on convenience sampling and was not intended to be statistically representative at the national scale, as data collection would have otherwise been too resource intensive. The aim was rather to reach as many forestry students as possible.

The questionnaire was developed based on a literature review, building on available examples of surveys on bioeconomy perceptions (e.g. Ranacher et al. 2017; Golowko et al. 2019) as well as on three rounds of expert feedback defined via brainstorming among authors (including students) to cover relevant topical aspects, including bioeconomy policy strategies.

The survey was pre-tested with students and amendments were made before final publication and launching. Data collection was done via Lime Survey between January and June 2019 with the support of MSc/PhD students in most of the countries. The survey was promoted via students mailing lists and social media. To increase success rate in data collection hard copy questionnaires were also distributed to students during different courses offered within forestry programs at hosting universities. Data were then manually transferred (though still kept identifiable) into the online survey system, in order to develop a common dataset.

A total of 1368 valid questionnaires was collected and used for data analysis. Table 1 and Appendix S2 summarize the distribution of valid questionnaires across the target countries and provide basic information on respondents.

With reference to the first research question, statistical data analysis was conducted by means of Microsoft Excel for descriptive statistics. For the second research question, a hierarchical cluster analysis was performed via $\mathrm{R}$ version 4.0.0, using Orange 3.25 for data visualization. The Ward (1963) algorithm (minimum variance method) was used to measure dissimilarity: it allows the creation of a cluster at each step by including the observations that lead to the minimum increase in the intra-cluster variance. The initial distance between observations is defined by the squared Euclidean distance. We draw conclusions about the similarity of two observations based on the location on the horizontal axis where branches containing those observations are merged (James et al. 2013). The analysis was based on 23 variables associated to questions of the questionnaire and organized into three main blocks, i.e. one for each research sub-question (2.1, 2.2 and 2.3) (Table 2). In order to support the decision about the number of clusters in the dendrogram, a Gap statistic was considered (Tibshirani et al. 2001). The applied algorithm compares the change in within-cluster dispersion with its expected value under the null hypothesis (i.e. no clustering). The higher the Gap statistic, the better the clustering. This analysis showed that the best clustering in our dataset is obtained with 5 clusters.

Data were analysed with regard to the whole sample and for single countries as well as university programs, in order to allow a comparative analysis and identify differences and similarities based on selected variables. The results are discussed vis-à-vis the existing literature on bioeconomy.

\section{RESULTS}

\section{To what degree have students heard} about bioeconomy?

About $70 \%$ of respondents have heard about bioeconomy: for all target countries the figure is higher than $50 \%$, ranging between $52 \%$ (ITA) and $100 \%$ (FIN) (Fig. 1). Values vary from North to South: in SWE and FIN figures are higher than $90 \%$, in Centre-West European countries (FRA, GER and AUT) figures are higher than $60 \%$, in East European countries (SVK and RUS) figures are higher than $70 \%$, and in South European countries (ITA and ESP) figures are lower than $60 \%$.

The percentage of respondents who have heard about bioeconomy increases from BSc (about 65\%) to MSc $(76 \%)$ and finally $\mathrm{PhD}(86 \%)$.

The main sources of information about bioeconomy identified by respondents are university courses (28\%)both in total and for six out of nine target countriesfollowed by news (16\%), scientific papers (15\%) and social media (15\%) and colleagues and conferences (7\% each) (Fig. 2).

Among courses that have been reported to address bioeconomy issues, courses in economics are the most cited ones (about 37\% of the total courses mentioned), followed by forest management (FM) and silviculture $(21 \%)$, policy $(16 \%)$, ecology $(14 \%)$ and technology (11\%).

In order to validate the reply to the question "have you heard about bioeconomy?" respondents were asked to show possible awareness of European and national bioeconomy strategies. The "Don't know" option resulted the most common one (63\% and $60 \%$ respectively) and although awareness is concentrated (90\%) among respondents who have heard already about bioeconomy these 
Table 1 Respondents' profile-Number and percentage of respondents per country, gender and study program

\begin{tabular}{|c|c|c|c|c|c|c|c|c|c|c|}
\hline Respondents & $\begin{array}{l}\text { AUT } \\
216\end{array}$ & $\begin{array}{l}\text { ESP } \\
68\end{array}$ & $\begin{array}{l}\text { FIN } \\
61\end{array}$ & $\begin{array}{l}\text { FRA } \\
21\end{array}$ & $\begin{array}{l}\text { GER } \\
237\end{array}$ & $\begin{array}{l}\text { ITA } \\
329\end{array}$ & $\begin{array}{l}\text { RUS } \\
81\end{array}$ & $\begin{array}{l}\text { SVK } \\
225\end{array}$ & $\begin{array}{l}\text { SWE } \\
130\end{array}$ & $\begin{array}{l}\text { TOTAL } \\
1368\end{array}$ \\
\hline \multicolumn{11}{|c|}{ Of which (per gender) } \\
\hline Female & 65 & 19 & 24 & 4 & 88 & 102 & 43 & 93 & 52 & 490 \\
\hline Male & 142 & 47 & 32 & 17 & 147 & 223 & 36 & 131 & 74 & 849 \\
\hline N/A* & 9 & 2 & 5 & - & 2 & 4 & 2 & 1 & 4 & 29 \\
\hline \multicolumn{11}{|c|}{ Of which (per study program) } \\
\hline $\mathrm{BSc}$ & 143 & 60 & 22 & 5 & 163 & 200 & 62 & 106 & 73 & 834 \\
\hline MSc & 66 & 8 & 35 & 6 & 54 & 118 & 14 & 109 & 45 & 455 \\
\hline $\mathrm{PhD}$ & 6 & - & 3 & 1 & 20 & 8 & - & 6 & 3 & 47 \\
\hline Other & - & - & - & 7 & - & 3 & 1 & - & 3 & 14 \\
\hline Blank & 1 & - & 1 & 2 & - & - & 4 & 4 & 6 & 18 \\
\hline Respondents, \% & $15.8 \%$ & $5.0 \%$ & $4.5 \%$ & $1.5 \%$ & $17.3 \%$ & $24.0 \%$ & $5.9 \%$ & $16.4 \%$ & $9.5 \%$ & $100.0 \%$ \\
\hline \multicolumn{11}{|c|}{ Of which (per gender) } \\
\hline Female, \% & $30.1 \%$ & $27.9 \%$ & $39.3 \%$ & $19.0 \%$ & $37.1 \%$ & $31.0 \%$ & $53.1 \%$ & $41.3 \%$ & $40.0 \%$ & $35.8 \%$ \\
\hline Male. \% & $65.7 \%$ & $69.1 \%$ & $52.5 \%$ & $81.0 \%$ & $62.0 \%$ & $67.8 \%$ & $44.4 \%$ & $58.2 \%$ & $56.9 \%$ & $62.1 \%$ \\
\hline N/A \% & $4.2 \%$ & $2.9 \%$ & $8.2 \%$ & - & $0.8 \%$ & $1.2 \%$ & $2.5 \%$ & $0.4 \%$ & $3.0 \%$ & $2.1 \%$ \\
\hline \multicolumn{11}{|c|}{ Of which (per study program) } \\
\hline BSc. $\%$ & $66.2 \%$ & $88.2 \%$ & $36.1 \%$ & $23.8 \%$ & $68.8 \%$ & $60.8 \%$ & $76.5 \%$ & $47.1 \%$ & $56.2 \%$ & $61.0 \%$ \\
\hline$M S c . \%$ & $30.6 \%$ & $11.8 \%$ & $57.4 \%$ & $28.6 \%$ & $22.8 \%$ & $35.9 \%$ & $17.3 \%$ & $48.4 \%$ & $34.6 \%$ & $33.3 \%$ \\
\hline PhD. \% & $2.8 \%$ & - & $4.9 \%$ & $4.8 \%$ & $8.4 \%$ & $2.4 \%$ & - & $2.7 \%$ & $2.3 \%$ & $3.4 \%$ \\
\hline Other. \% & - & - & - & $33.3 \%$ & - & $0.9 \%$ & $1.2 \%$ & - & $2.3 \%$ & $1.0 \%$ \\
\hline Blank. \% & $0.5 \%$ & - & $1.6 \%$ & $9.5 \%$ & - & - & $4.9 \%$ & $1.8 \%$ & $4.6 \%$ & $1.3 \%$ \\
\hline
\end{tabular}

AUT Austria, ESP Spain, FIN Finland, FRA France, GER Germany, ITA Italy, RUS Russian Federation, SVK Slovakia, SWE Sweden, N/A not indicated or not reported

remain largely undecided (57\% and 47\%). Despite some differences among countries, awareness of European/national strategies, as well as the incidence of university courses as a source of information, tend to increase along students' careers, i.e. from BSc to MSc and finally PhD.

\section{Cluster analysis}

Results of the cluster analysis are summarized in Fig. 3 and discussed below.

When the whole dataset is considered (Fig. 3a), four clusters (C1, C3, C4 and C5) and one outlier (C2) are observed. The latter corresponds to FIN PhD that would fuse at much higher distances and do not fit into the analysis. Also $\mathrm{C} 1$, including FRA and SWE PhD, is visibly isolated from the rest of the clusters and their merging seems to be quite arbitrary. FRA, FIN and SWE are the countries with the lowest number of $\mathrm{PhD}$ respondents and this might explain their isolation. In general terms, the distance between $\mathrm{PhD}$ and BSc-MSc is larger (i.e. higher difference) than the distance between BSc and MSc within the same country. The shortest distance (i.e. higher similarity) between BSc and MSc within the same country is observed for SVK, with a convergence inside $\mathrm{C} 4$ at a rather low value on the horizontal axis, followed by FIN, AUT, GER and SWE. On the contrary, the gap between ITA, ESP and FRA and RUS BSc and MSc is larger as they converge at higher distances. Convergence is also observed between university programs across countries: this is in particular the case for AUT and GER BSc as well as MSc, forming the bulk of C4, and ESP and ITA BSc (C2). Cross-country convergence is faster for BSC than other groups.

Given the limited number of $\mathrm{PhD}$ respondents, their uneven distribution across countries, with a strong concentration in GER and no respondents for ESP and RUS, we decided to focus on BSc and MSc (Fig. 3b). Overall, 4 clusters $(\mathrm{C} 1, \mathrm{C} 2, \mathrm{C} 4$ and $\mathrm{C} 5)$ and one outlier (C3, i.e. FRA MSc) have been identified. They are described below, vis$a$-vis the different blocks of variables analysed (see Table 2). 
Table 2 Variables used for the cluster analysis, their description, name in short and basic statistical values

\begin{tabular}{|c|c|c|c|c|c|c|c|c|c|}
\hline \multicolumn{4}{|c|}{ Variables } & \multicolumn{6}{|c|}{ Basic statistical values } \\
\hline Block & Description & & In short* & Median & Mean & $\begin{array}{l}\mathrm{SE} \\
\text { mean }\end{array}$ & Var & Std.Dev & Coef.Var \\
\hline \multirow[t]{3}{*}{2.1} & \multirow{3}{*}{$\begin{array}{l}\text { Bioeconomy within } \\
\text { attended university } \\
\text { programs }\end{array}$} & $\begin{array}{l}\text { Perception of the extent to which } \\
\text { bioeconomy is currently addressed }\end{array}$ & $\mathrm{S} 23$ & 2.85 & 3.03 & 0.10 & 0.28 & 0.52 & 0.17 \\
\hline & & $\begin{array}{l}\text { Satisfaction with the extent to which } \\
\text { bioeconomy is currently addressed }\end{array}$ & $\mathrm{S} 24$ & 2.55 & 2.52 & 0.10 & 0.28 & 0.51 & 0.20 \\
\hline & & $\begin{array}{l}\text { Extent to which bioeconomy should be } \\
\text { addressed more within student's university } \\
\text { program }\end{array}$ & S25 & 3.12 & 3.12 & 0.13 & 0.42 & 0.63 & 0.20 \\
\hline \multirow[t]{2}{*}{2.2} & \multirow{2}{*}{$\begin{array}{l}\text { Perceived current role of } \\
\text { forests within } \\
\text { bioeconomy }\end{array}$} & At European level & S35 & 4.16 & 4.17 & 0.07 & 0.14 & 0.36 & 0.09 \\
\hline & & At country level & S37 & 4.00 & 4.10 & 0.11 & 0.32 & 0.55 & 0.13 \\
\hline \multirow[t]{6}{*}{$2.3 \mathrm{a}$} & \multirow{6}{*}{$\begin{array}{l}\text { Aspects/issues developed } \\
\text { through FBB nowadays }\end{array}$} & Totally new products $\&$ technologies & S39New & 3.33 & 3.49 & 0.12 & 0.37 & 0.60 & 0.17 \\
\hline & & Improvement of existing products & S39Imp & 3.64 & 3.59 & 0.09 & 0.23 & 0.47 & 0.13 \\
\hline & & Efficient use of forest-based product & S39Eff & 3.79 & 3.79 & 0.06 & 0.11 & 0.32 & 0.08 \\
\hline & & New uses for existing products & S39New & 3.50 & 3.48 & 0.06 & 0.10 & 0.31 & 0.09 \\
\hline & & $\begin{array}{l}\text { Substitution of fossil fuels with forest } \\
\text { biomass for energy purposes }\end{array}$ & S39Sub & 3.58 & 3.65 & 0.11 & 0.32 & 0.56 & 0.15 \\
\hline & & $\begin{array}{l}\text { Multiple services/products offered by forests } \\
\text { (e.g. ecosystem services) }\end{array}$ & S39Es & 3.41 & 3.44 & 0.10 & 0.24 & 0.48 & 0.14 \\
\hline \multirow[t]{6}{*}{$2.3 \mathrm{~b}$} & \multirow{6}{*}{$\begin{array}{l}\text { Perceived FBB } \\
\text { development drivers } \\
\text { and orientations }\end{array}$} & Technological developments & S311Tec & 3.53 & 3.51 & 0.11 & 0.33 & 0.56 & 0.16 \\
\hline & & Oriented to products & S311Pro & 3.44 & 3.51 & 0.06 & 0.11 & 0.32 & 0.09 \\
\hline & & Oriented to multiple services & S311Ser & 3.79 & 3.77 & 0.07 & 0.12 & 0.33 & 0.09 \\
\hline & & Based on local natural resources & S311Lres & 4.13 & 4.16 & 0.07 & 0.15 & 0.37 & 0.09 \\
\hline & & $\begin{array}{l}\text { Based on natural resources (no matter if local } \\
\text { or imported) }\end{array}$ & S311Nres & 3.00 & 2.94 & 0.11 & 0.29 & 0.53 & 0.18 \\
\hline & & $\begin{array}{l}\text { Combination of new and traditional } \\
\text { knowledge }\end{array}$ & S311N\&TK & 4.14 & 4.11 & 0.07 & 0.13 & 0.35 & 0.09 \\
\hline \multirow[t]{6}{*}{$2.3 \mathrm{c}$} & \multirow{6}{*}{$\begin{array}{l}\text { Perceived FBB } \\
\text { development impacts }\end{array}$} & Promote employment opportunities & S311Emp & 4.00 & 3.98 & 0.08 & 0.18 & 0.42 & 0.10 \\
\hline & & $\begin{array}{l}\text { Favour sustainable forest management } \\
\quad(\mathrm{SFM})\end{array}$ & S311SFM & 4.16 & 4.07 & 0.11 & 0.31 & 0.55 & 0.13 \\
\hline & & Promote FM at local scale & S311LoFM & 3.84 & 3.84 & 0.09 & 0.23 & 0.47 & 0.12 \\
\hline & & Promote FM, no matter at which scale & S311FM & 3.59 & 3.68 & 0.09 & 0.20 & 0.43 & 0.12 \\
\hline & & Increased deforestation/forest degradation & S311Def & 2.33 & 2.25 & 0.11 & 0.30 & 0.54 & 0.24 \\
\hline & & $\begin{array}{l}\text { Increased people's awareness of } \\
\text { environmental and forestry issues }\end{array}$ & S311Awa & 3.79 & 3.73 & 0.13 & 0.42 & 0.63 & 0.17 \\
\hline
\end{tabular}

Variable values have been obtained from survey data by averaging values per country and attended program (i.e. BSC,MSc and PhD). See additional material available in Appendix S1 for more details and referenced questions

\section{Bioeconomy within attended university programs}

Cluster 1, C1 (FIN and SWE BSc and MSc, RUS BSc) includes respondents who perceive bioeconomy as moderately addressed within the university programs they attend (Fig. 4a) are little to rather satisfied and ask the bioeconomy is taught from rather more to more. The most satisfied respondents are FIN BSc and MSc.

Clusters 2 (ESP, FRA and ITA BSc) and 5 (ESP, ITA and RUS MSc) include the least satisfied respondents.
Cluster 2 (C2) associates this with the lowest perceived extent to which bioeconomy is currently addressed and the highest request for more bioeconomy teaching. Cluster 5 (C5), on the contrary, represents the highest perception of the extent to which bioeconomy is addressed, but also the biggest dissatisfaction of respondents as well as the lowest request for bioeconomy to be taught more.

Cluster 4 (C4; AUT, GER, SVK BSc and MSc) lays between $\mathrm{C} 1, \mathrm{C} 2$ and $\mathrm{C} 5$ and shows intermediate values for all variables: this means that students are little to rather 
(a) Total

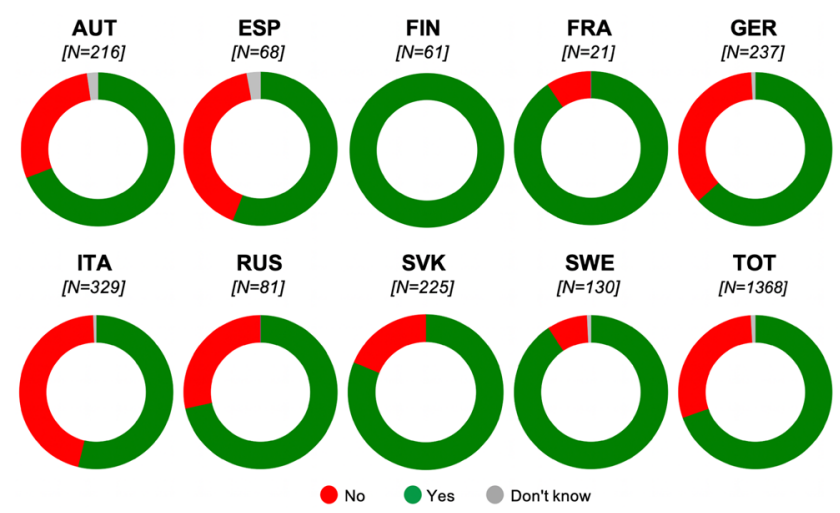

(c) $M S C$

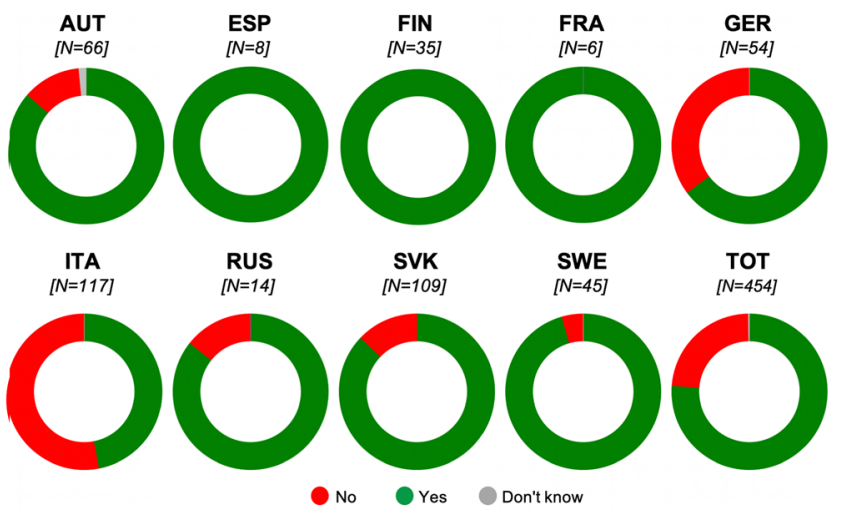

(b) $B S c$

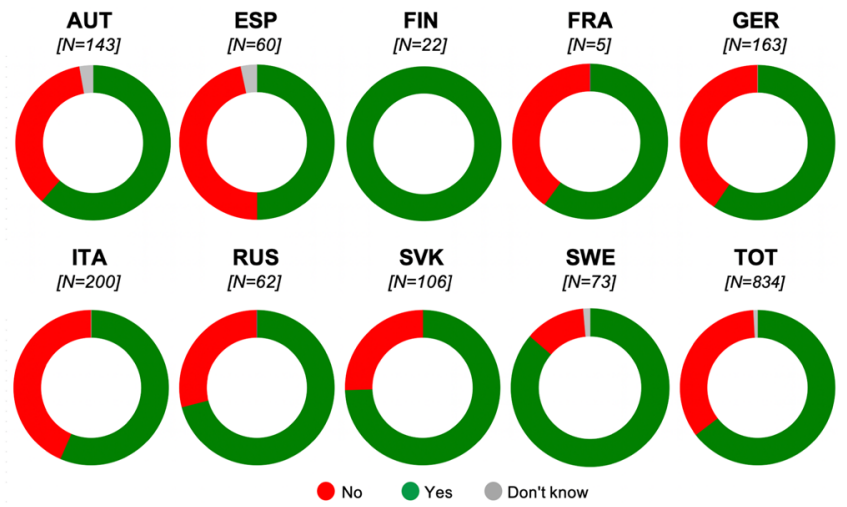

(d) $P h D$
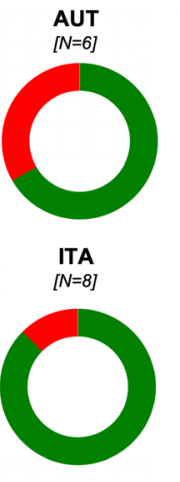
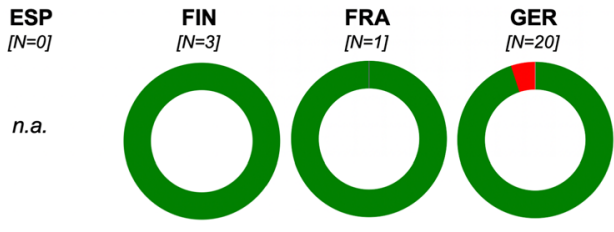

RUS
$[N=0]$

n.a.

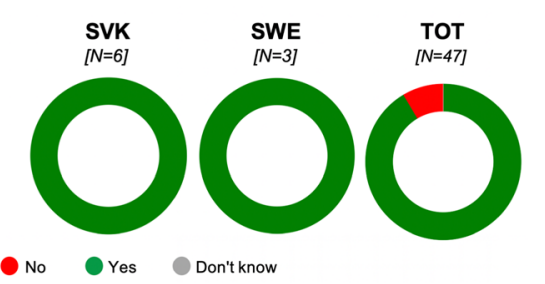

Fig. 1 Respondents who have (yes)/haven't (no) heard about bioeconomy: figures for all respondents and per attended program

satisfied with the current teaching and that they wish bioeconomy to be a bit more addressed within their programs. C3 (FRA MSc) falls between C4 and C5: despite reporting the second highest value for the perceived extent to which bioeconomy is addressed, it also shows moderate to low levels of satisfaction and students' requests for more bioeconomy teaching.

BSc tend to concentrate in the upper-left part of Fig. 4a, while MSc tend to concentrate in the lower-right part. As indicated by the larger gap between $\mathrm{C} 1$ and $\mathrm{C} 3 / \mathrm{C} 5$, if compared to the one within $\mathrm{C} 1$ and $\mathrm{C} 4$, the within-country BSc-MSc gap is larger for ESP, FRA and ITA than for AUT, FIN, GER, SVK and SWE. The most evident BScMSc gap is observed for ITA, while the lowest ones for SVK, FIN, AUT and SWE.

\section{The importance of forests within a bioeconomy}

C1 includes respondents perceiving the highest values for forests at both country and European level and showing a positive difference (gap) between them (up to +0.5 ). RUS BSc does not fit very well in $\mathrm{C} 1$, as it shows a negative gap. $\mathrm{C} 2$ and C5 present the lowest perceived values at country level and the largest negative gaps $(-0.6$ to -0.7$)$ with the importance of forests within a bioeconomy perceived at the European level. ITA BSc (C2) and ESP MSc (C5) present higher values than their cluster members, but still show negative gaps of the same magnitude. $\mathrm{C} 3$ and $\mathrm{C} 4$ fall between $\mathrm{C} 1, \mathrm{C} 2$ and $\mathrm{C} 5$. C3 presents the lowest value for the European level and a positive gap similar to the one observed for FIN. As for C4, AUT and GER BSc show similar values, including the gap (0.2), and AUT and GER MSc have zero gaps (Fig. 4b).

\section{The development of a forest-based bioeconomy}

With regard to aspects perceived as developed through $F B B$ nowadays, $\mathrm{C} 1$ shows the highest value for the development of totally new products and technologies as well as the substitution of fossil fuels, followed by 


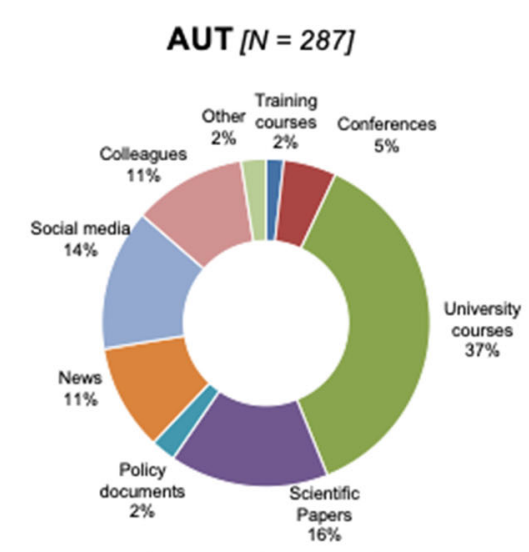

FRA [ $N=57]$

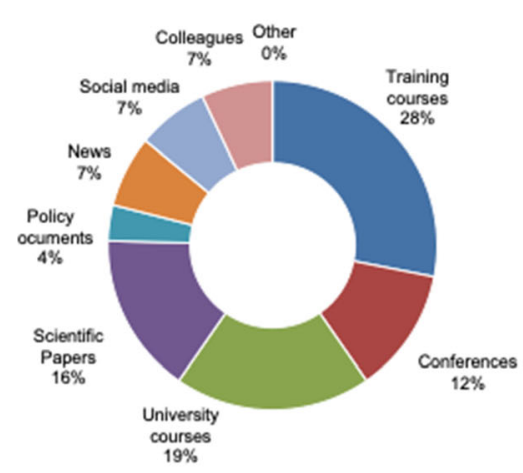

RUS [N = 123]

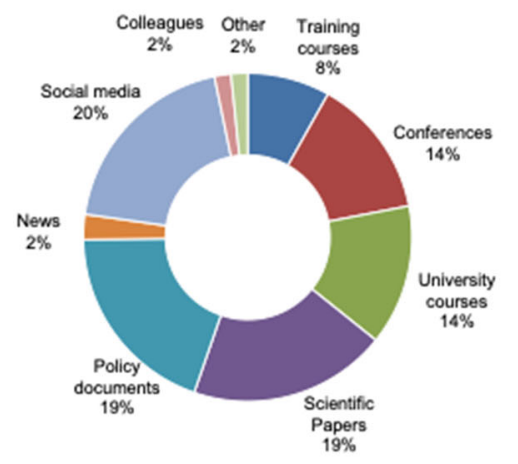

TOTAL [ $N=2239]$

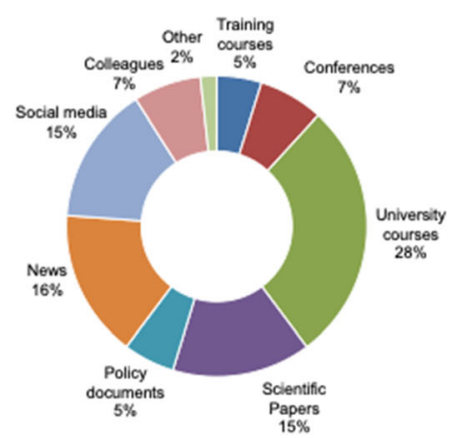

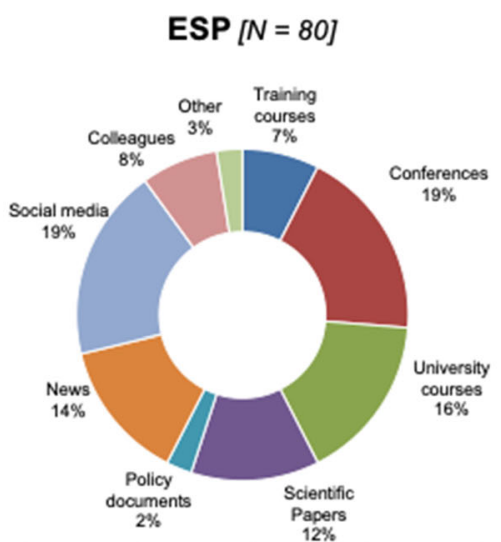

GER [ $N=321]$

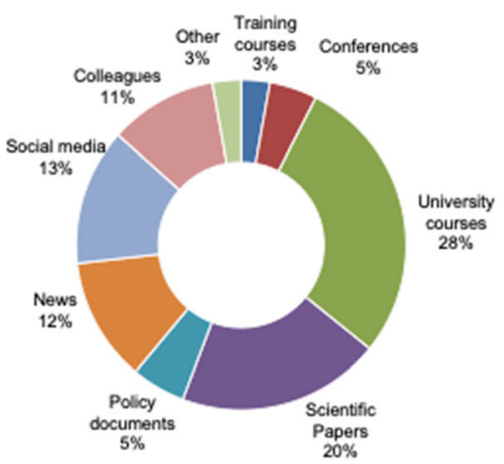

SVK $[N=343]$

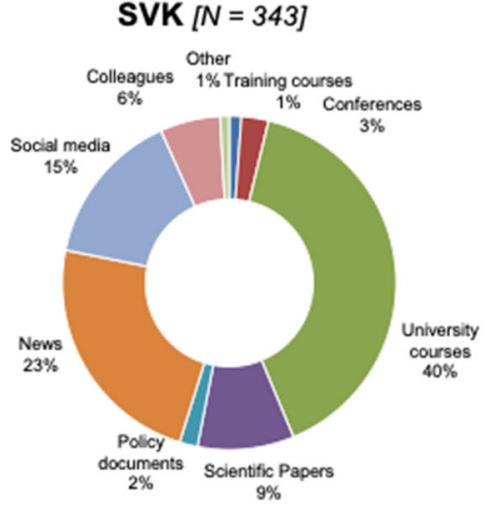

FIN $[N=280]$

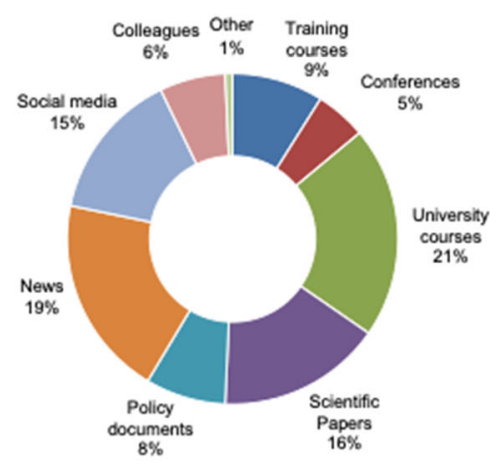

ITA $[N=392]$

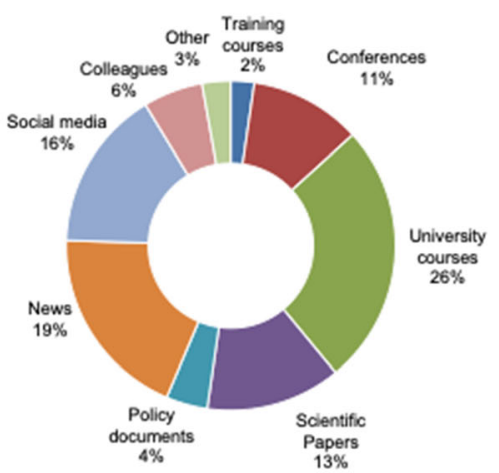

SWE $[N=356]$

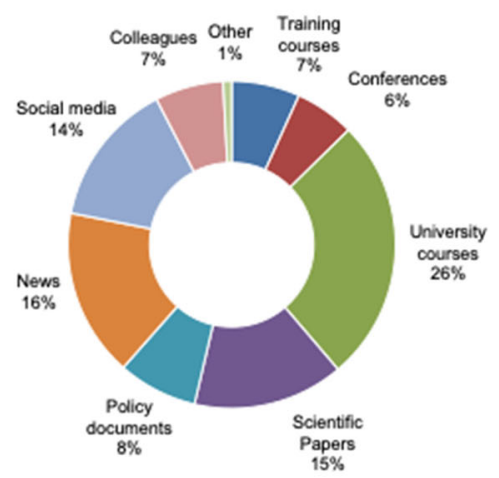

Fig. 2 Main information sources on bioeconomy for respondents. Note Multiple choices are allowed; therefore, total values do not equal the number of respondents. AUT Austria, ESP Spain, FIN Finland, FRA France, GER Germany, ITA Italy, RUS Russian Federation, SLK Slovakia, SWE Sweden

\section{Legend:}

\begin{tabular}{|c|c|c|}
\hline - Training courses & - Conferences & - University courses \\
\hline - Scientific Papers & "Policy documents & News \\
\hline Social media & Colleagues & Other \\
\hline
\end{tabular}


(a) BSc, MSC and PhD

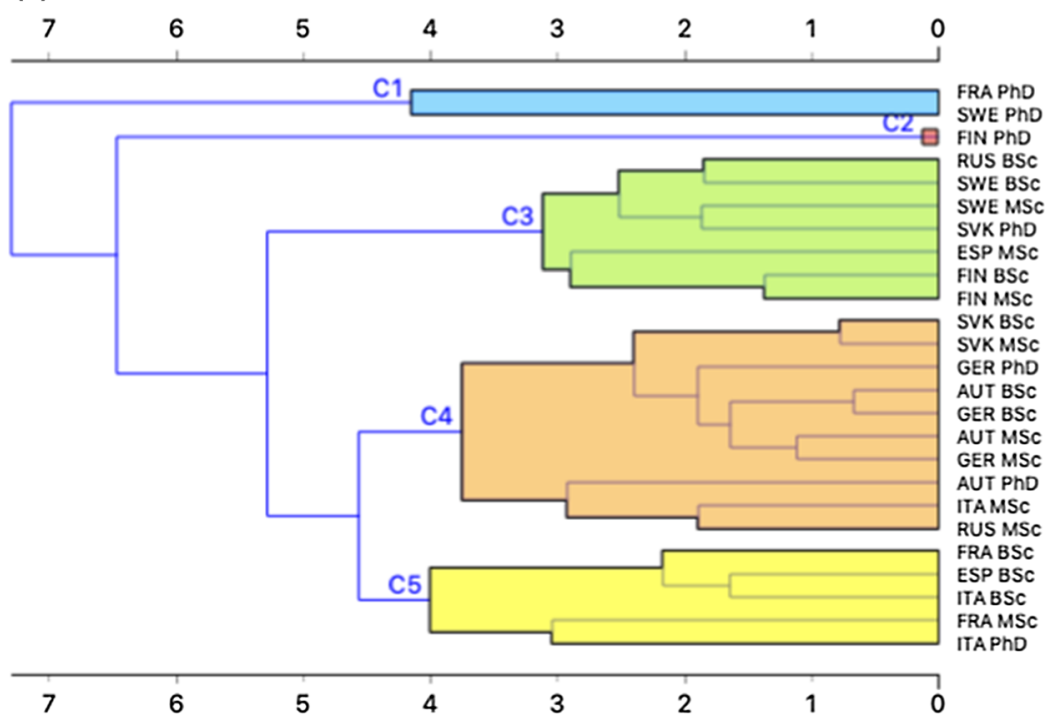

(b) $B S C$ and $M S C$

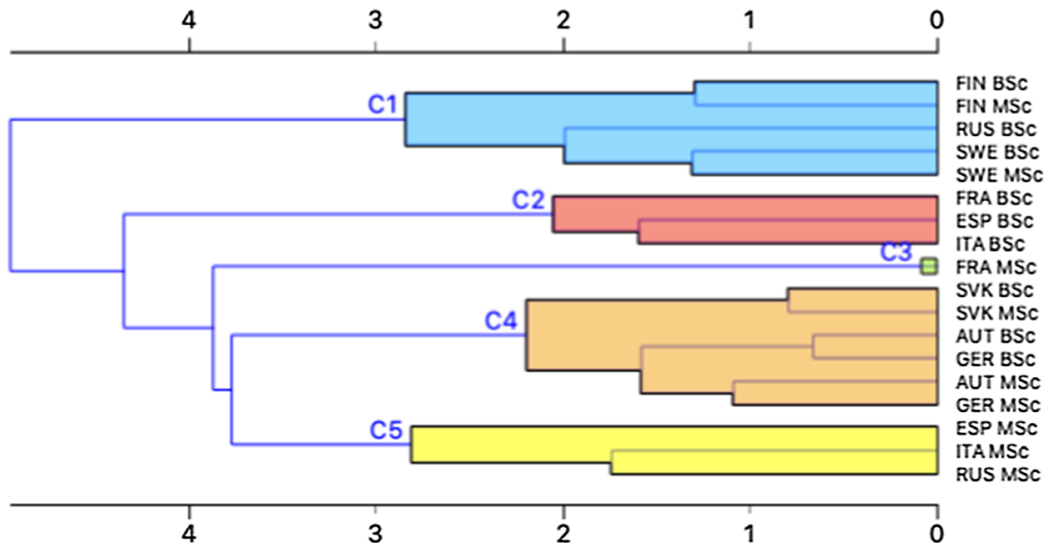

Fig. 3 Hierarchical cluster analysis dendrograms showing different clusters identified via 23 variables reported in Table 2 for two different datasets considered: a BSc, MSc and $\mathrm{PhD}$ and $\mathbf{b}$ BSc and $\mathrm{MSc}$

improved products and efficiency. C2 presents the lowest values for all variables, in particular with reference to the development of new products and substitution. C5 is similar to $\mathrm{C} 1$, but shows higher values for the development of new products (and technologies) and ecosystem services and lower for the fossil fuel substitution. C3 presents values higher than 4 for all variables but substitution, for which it shows values similar to $\mathrm{C} 2$ and $\mathrm{C} 5$. When compared to $\mathrm{C} 2$ and $\mathrm{C} 5, \mathrm{C} 4$ shows higher values for efficiency and substitution, but lower for ecosystem services.

The development of new products and technologies and the substitution of fossil fuels and ecosystem services seem to be the most polarizing issues (Figs. 4c and d). As for substitution, $\mathrm{C} 1$ and $\mathrm{C} 4$ show medium to high values, standing above all other clusters; $\mathrm{C} 1$ and $\mathrm{C} 3$ have values higher than 4 for the development of new products (except for RUS BSc) and C3 and C5 have the highest values for ecosystem services, although ITA BSc (C2) and SWE BSc and MSc $(\mathrm{C} 1)$ show high values too.

With reference to the perceived $F B B$ development drivers and orientations, $\mathrm{C} 1$ and $\mathrm{C} 5$ perceive the highest role for technology as a bioeconomy driver together with the perception that bioeconomy shall be oriented towards products. The remaining clusters show a much lower perceived value for both technology (in particular C2 and C3) and products (Fig. 4e). C2 and C3 highly perceive the FBB to be oriented towards ecosystem services, while all other clusters report lower values. All clusters tend to agree about the use of local resources, as well as the combination of new and traditional knowledge: for the two of them all rates are higher than 4 . When considering the use of natural resources regardless of their origin (i.e. no matter if locally or imported), the range of perceptions is much broader: $\mathrm{C} 1$, C5 as well as SVK BSc and MSc (C4) are open to the 
(a) Block 2.1 - Bioeconomy within attended university programs

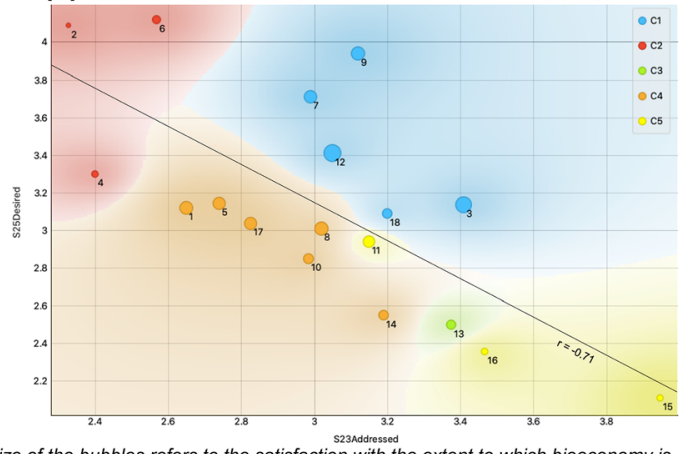

*size of the bubbles refers to the satisfaction with the extent to which bioeconomy is perceived to be currently addressed within studentis university program (S25)

(c) Block 2.2b - New products and Substitution

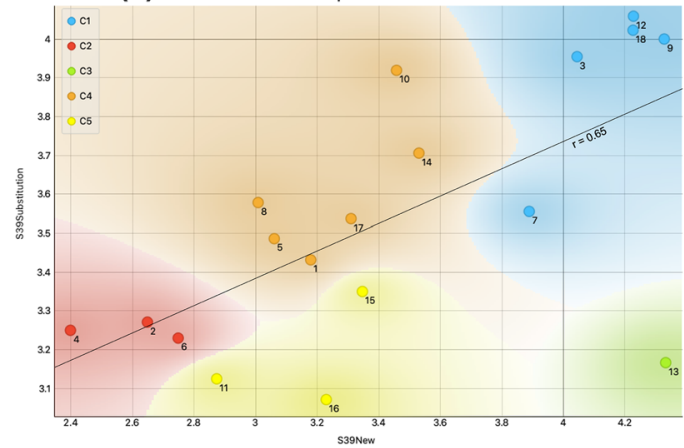

(e) Block 2.2c- Product and Technology

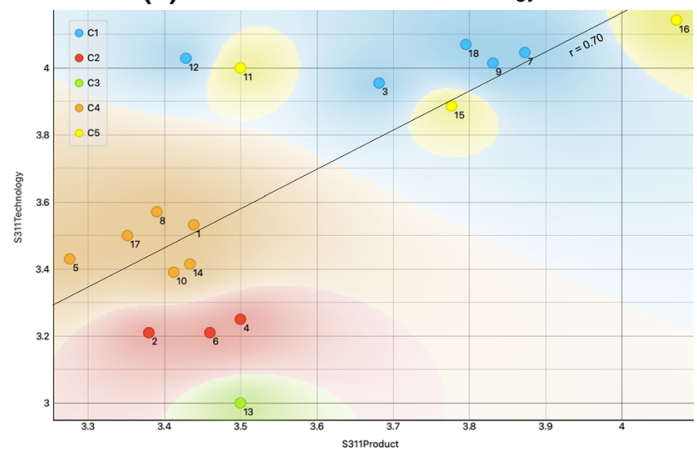

(g) Block 2.2.d-Forest management and Local forest management

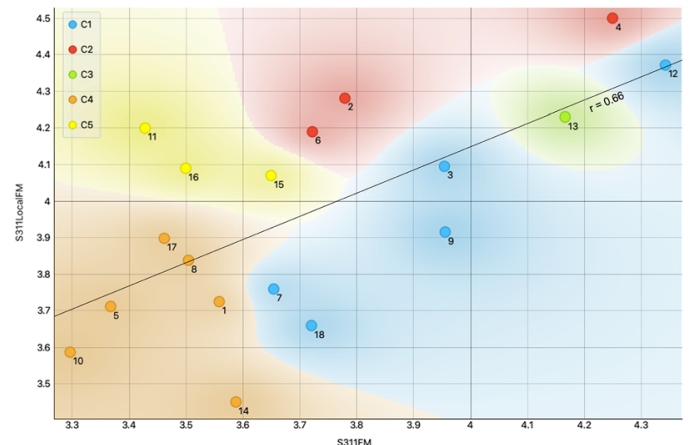

(b) Block 2.2a - Perceived current role of forests within bioeconomy

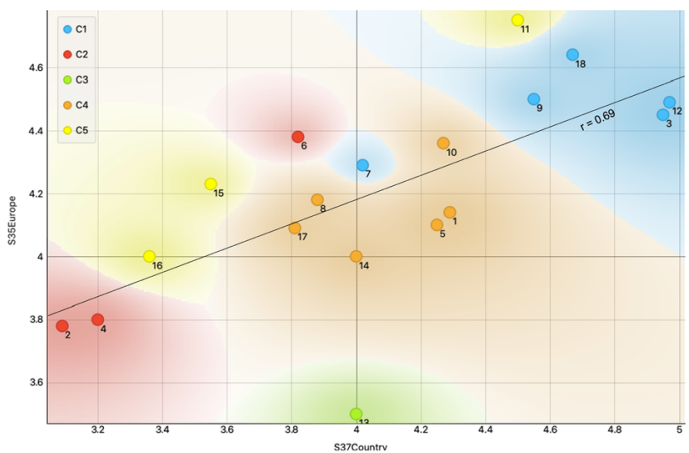

(d) Block 2.2b - New products and Ecosystem services

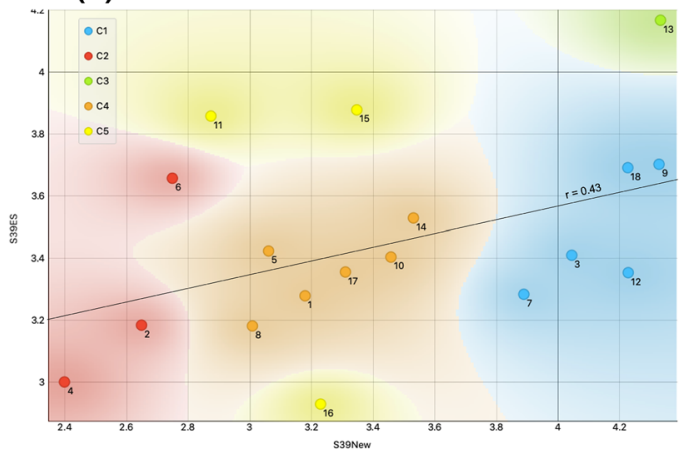

(f) Block 2.2c - Natural resources and Local natural resources

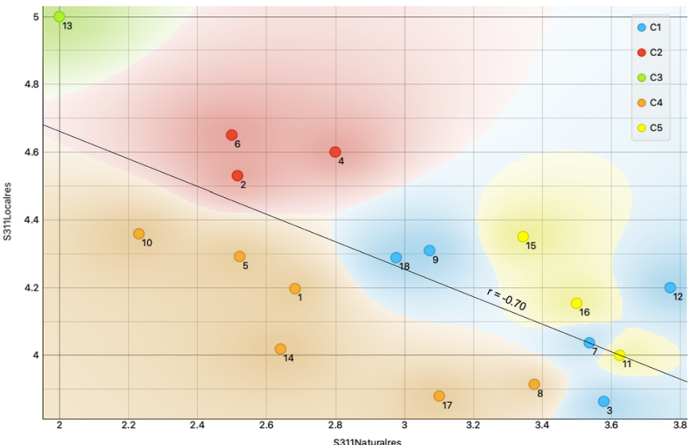

(h) Perceived current role of forests at country leve and Local forest management

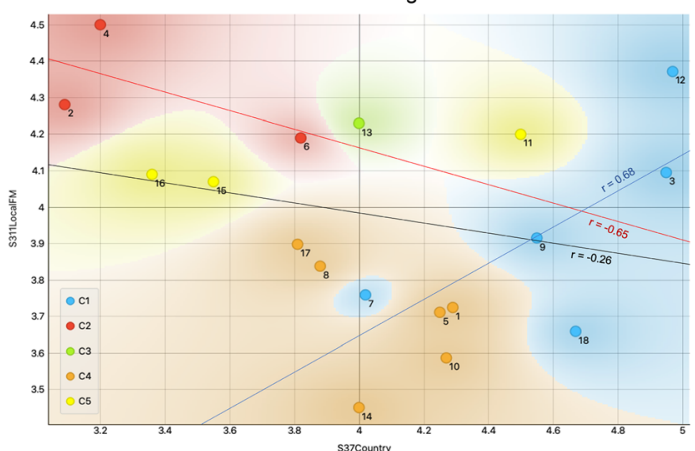

Fig. 4 Plot charts of key variables used for the cluster analysis. Note: 1. AUT BSc, 2. ESP BSc, 3. FIN BSc, 4. FRA BSc, 5. GER BSc, 6. ITA BSc, 7. RUS BSc, 8. SVK BSc, 9. SWE BSc, 10. AUT MSc, 11. ESP MSc, 12. FIN MSc, 13. FRA MSc, 14. GER MSc, 15. ITA MSc, 16. RUS MSc, 17. SVK MSc, 18. SWE MSc, 19. AUT PhD, 20. FIN PhD, 21. FRA PhD, 22. GER PhD, 23. ITA PhD, 24. SVK PhD and 25. SWE PhD 
(a) Bioeconomy within attended university programs

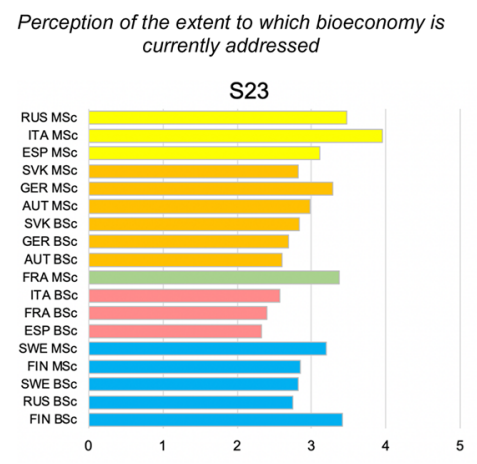

Satisfaction with the extent to which bioeconomy is currently addressed

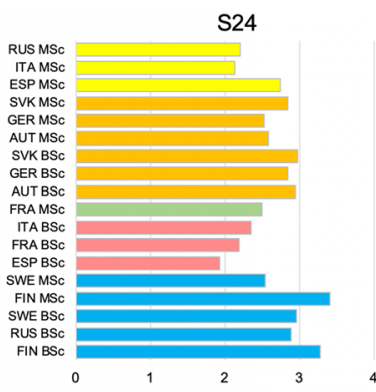

Extent to which bioeconomy should be addressed more within studentis university program

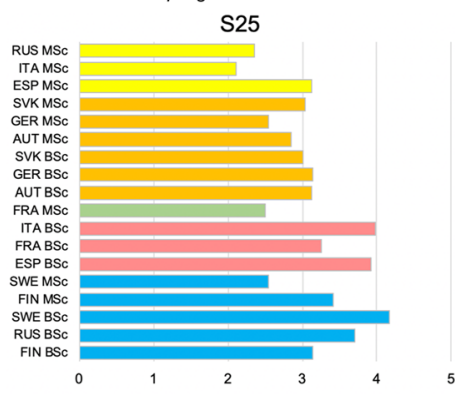

(b) Perceived current role of forests within bioeconomy
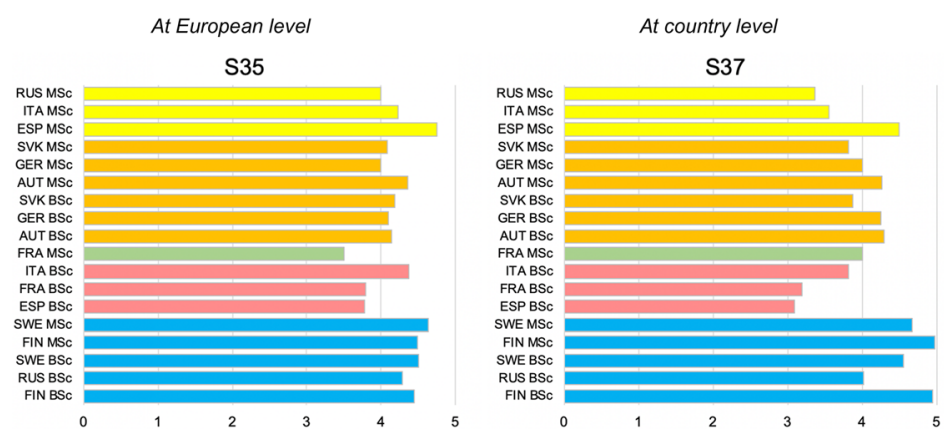

Fig. 5 Clustering of perceived values for a bioeconomy within attended university programs (variable block 2.1) and $\mathbf{b}$ perceived current role of forests within bioeconomy (variable block 2.2)

possibility of using non-local resources (moderate agreement). On the contrary, C2, C3 and C4 (excluding SVK) rather disagree with this idea as they seem to be more in favour of local resources (Fig. 4f).

Finally, with reference to the perception of possible $F B B$ impacts, (C1), FRA BSc (C2) and MSc (C3) understand the development of a bioeconomy to promote FM both locally and at a broader scale. $\mathrm{C} 2$ and $\mathrm{C} 5$ are more oriented towards the idea that a FBB will support local FM activities (Fig. 4g). The promotion of local FM via FBB can be linked to the perceived role of national forests within bioeconomy (Fig. 4h). In the case of $\mathrm{C} 1$, the development of a FBB might be regarded as an opportunity to further reinforce the local/national forest sector, while in the case of $\mathrm{C} 2$, it may provide an opportunity to enhance it. This may also be linked to additional benefits: $\mathrm{C} 2$ (as well as $\mathrm{C} 5$ and C3) strongly perceive that the development of a FBB will promote employment opportunities.

All clusters tend to agree with the idea that the development of a bioeconomy will favour sustainable forest management (SFM); however, C4 (AUT and GER) shows a fully undecided position.

The key results of the clustering exercise are reported in Figs. 5 and 6 in the form of a visual summary and mapping of clusters and their main features.

\section{DISCUSSION}

\section{Bioeconomy: a flowing and waving master narrative}

The word "bioeconomy" and related terminology is increasingly mentioned within technical and policy documents and is gaining traction in public and media discourse, as it has been emphatically defined as "panacea for sustainable competitive growth" (Philippidis et al. 2016). Not surprisingly, then, about $70 \%$ of the respondents reported to have heard about it and this percentage grows up to $100 \%$ for forestry students in FIN. Having heard about bioeconomy doesn't necessarily imply that students completely understand it and are familiar with it. Being familiar includes "perceiving, interpreting, remembering and responding to stimuli" (Purdy 1997, p. 8) as necessary steps for processing information and a primary channel of learning processes (Duck and McMahan 2017). Respondents reported university courses to be their main source of information on bioeconomy: this confirms the role of HEI in contributing to a transition towards a bioeconomy as emphasized by several policy documents, including the EC Bioeconomy Strategy (EC 2018). However, since the rise of the importance of a bioeconomy is quite recent, building of an effective education system by HEI for addressing it 


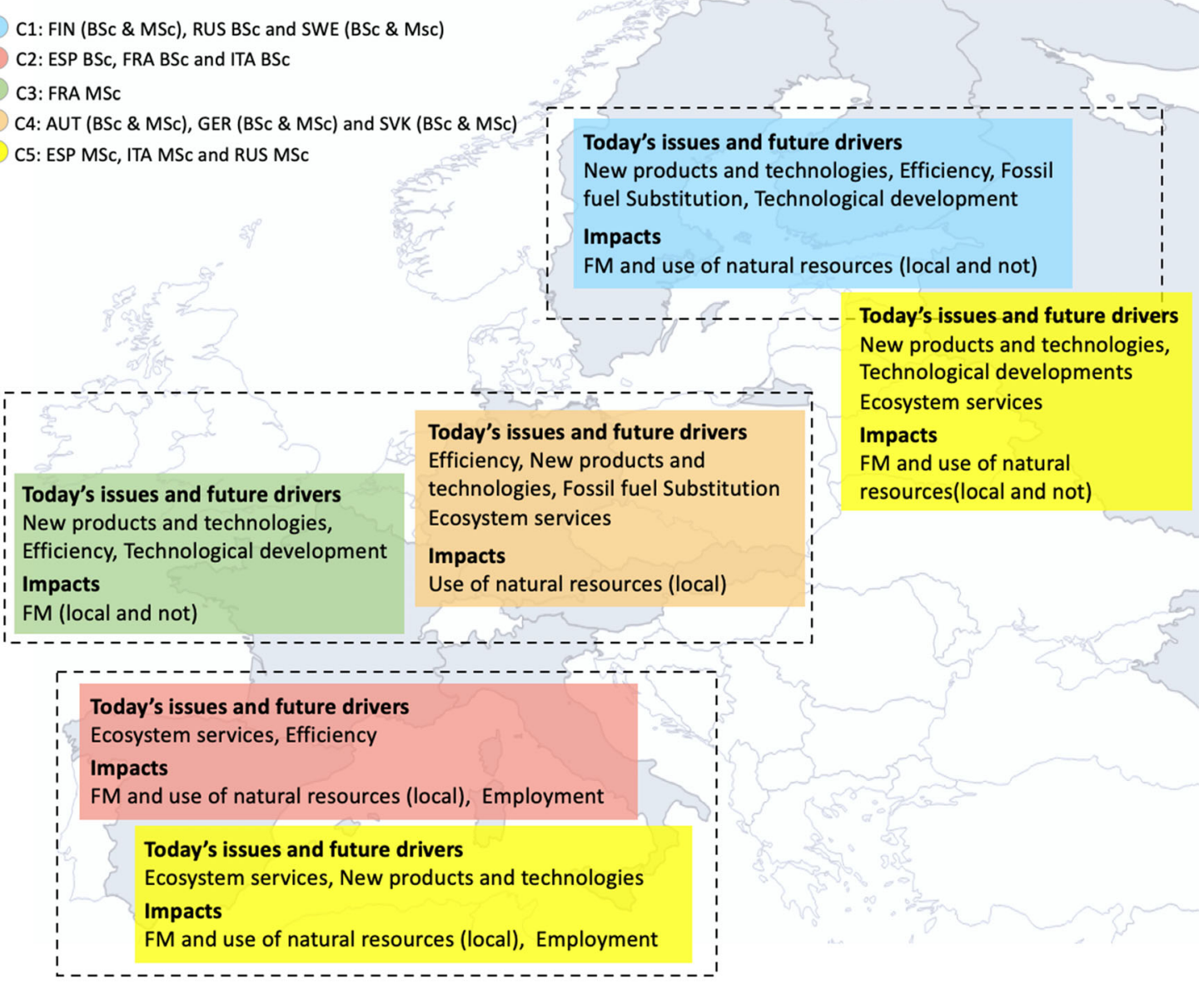

Fig. 6 Visual summary and mapping of clustering for perceived FBB today's issues, future drivers and impacts (variable block 2.3)

systematically and critically is still at the early stages. Almost one-third of respondents stated that the bioeconomy concept is a completely new and unknown to them and that they cannot provide a definition. Based on respondents' feedback, bioeconomy is perceived from different perspectives and with slightly different meanings. Complex terms/concepts, like bioeconomy, tend to be understood only subjectively and are individually interpreted (Golowko et al. 2019). This will likely result in several different developments of the bioeconomy, as confirmed by respondents' associations focusing on different topics such as technology developments, ecosystem services or substitution. Students' perceptions confirm findings from previous studies, i.e. the meaning of bioeconomy "still seems in a flux" (Pülzl et al. 2014, p. 386) and it can be characterized as a "master narrative" (Delvenne and Herndrickx 2013, p. 75; Levidow et al. 2013, p. 95), which is open for very different interpretations and conceptions (Kleinschmit et al. 2014; Pfau et al. 2014; Bugge et al. 2016; D'Amato et al. 2017; Hausknost et al. 2017; Bauer 2018; Vivien et al. 2019).

\section{More bioeconomy at university: more of what?}

Bioeconomy is addressed unevenly across different university programs in Europe and so is its embodying within targeted universities. This reflects on the level of satisfaction with the extent to which bioeconomy is perceived to be addressed: overall about $40 \%$ of respondents are not/little satisfied and about $90 \%$ of respondents would like to have more bioeconomy taught within their university programs. Clustering allows identifying differences across both countries and university programs. The least satisfied are students from ESP, FRA, ITA and RUS (MSc) while higher satisfaction is reported for all other countries, in particular for FIN. All in all, countries that have been the first (as early as 2011) in Europe to start developing national bioeconomy discourses, such as AUT, GER and FIN, reported bioeconomy to be more addressed and students to be more satisfied.

BSc and MSc reported different perceptions: the former group perceives bioeconomy as being too little addressed and would like to have more bioeconomy-related courses at their home institutions. However, differences regarding 
Table 3 FBB development routes based on student's perceptions vis-à-vis existing literature

\begin{tabular}{|c|c|c|c|}
\hline & Northern Europe & Central Europe & Southern Europe \\
\hline Countries & $\begin{array}{l}\text { FIN and SWE } \\
\text { (RUS) }\end{array}$ & $\begin{array}{l}\text { AUT and GER } \\
\text { (SVK, FRA MSc) }\end{array}$ & $\begin{array}{l}\text { ITA and ESP } \\
\text { (FRA BSc) }\end{array}$ \\
\hline Clusters & $\mathrm{C} 1$ & C4 (C3) & $\mathrm{C} 2$ (C5) \\
\hline $\begin{array}{l}\text { Today's issues and } \\
\text { future drivers }\end{array}$ & $\begin{array}{l}\text { New products } \\
\text { Efficiency } \\
\text { Fossil fuel Substitution } \\
\text { Technology }\end{array}$ & $\begin{array}{l}\text { Efficiency } \\
\text { New products } \\
\text { Fossil fuel Substitution } \\
\text { Technology } \\
\text { Ecosystem services }\end{array}$ & $\begin{array}{l}\text { Ecosystem services } \\
\text { New products }\end{array}$ \\
\hline $\begin{array}{l}\text { Impacts } \\
\text { (see Figs. } 5 \text { and 6) }\end{array}$ & $\begin{array}{l}\text { FM and use of natural } \\
\text { resources (local and not) }\end{array}$ & $\begin{array}{l}\text { Use of natural resources } \\
\text { (local) }\end{array}$ & $\begin{array}{l}\text { FM and use of natural } \\
\text { resources (local) } \\
\text { Employment }\end{array}$ \\
\hline $\begin{array}{l}\text { Bioeconomy visions } \\
\text { a. Bugge et al. (2016) } \\
\text { b. Hausknoft et al. (2018) } \\
\text { c. Vivien et al. (2019) }\end{array}$ & $\begin{array}{l}\text { a. Bio-technology/Bio- } \\
\text { resource } \\
\text { b. Sustainable Capital/Planned } \\
\text { Transition } \\
\text { c. Life science, Type II and III }\end{array}$ & $\begin{array}{l}\text { a. Bio-resource/Bio- } \\
\text { technology } \\
\text { b. Sustainable Capital/Eco- } \\
\text { Growth } \\
\text { c. Type II and III }\end{array}$ & $\begin{array}{l}\text { a. Bio-resource/Bio-Ecology } \\
\text { b. Eco-Growth/Eco-Retreat } \\
\text { c. Type I and III }\end{array}$ \\
\hline $\begin{array}{l}\text { Transition paths (TP), decreasing importance/ } \\
\text { prevalence } \\
\text { (Dietz et al. 2018) }\end{array}$ & $\begin{array}{l}\text { TP1-Substitution } \\
\text { TP2-Productivity increase } \\
\text { TP3-Efficiency increase } \\
\text { TP4-Value creation }\end{array}$ & $\begin{array}{l}\text { TP3-Efficiency increase } \\
\text { TP2-Productivity increase } \\
\text { TP1-Substitution } \\
\text { TP4-Value creation }\end{array}$ & $\begin{array}{l}\text { TP4-Value creation } \\
\text { TP3-Efficiency increase } \\
\text { TP1-Substitution } \\
\text { TP2-Productivity increase }\end{array}$ \\
\hline $\begin{array}{l}\text { Innovation process } \\
\text { Rametsteiner and Weiss (2006) } \\
\text { Hansen et al. (2011) } \\
\text { Secco et al. (2018) }\end{array}$ & Mainly linear & $\begin{array}{l}\text { Mainly linear with some } \\
\text { interactive components }\end{array}$ & $\begin{array}{l}\text { Mainly interactive with some } \\
\text { linear components }\end{array}$ \\
\hline $\begin{array}{l}\text { Perceived current importance of national forests } \\
\text { within transition to a FBB } \\
\text { (see Fig. 4) }\end{array}$ & Very high & High & Medium/Low \\
\hline
\end{tabular}

*Variable values have been obtained from survey data by averaging values per country and attended program (i.e. BSC, MSc and PhD). See additional material available in S1 for more details and referenced questions

perceived satisfaction across $\mathrm{BSc}$ and $\mathrm{MSc}$ groups are nuanced and country specific.

It is not easy to say how "more bioeconomy within university programs" should be interpreted based only on survey results, because this question was not explicitly asked for. When comparing responses to different questions across the whole questionnaire it can be argued that respondents are asking to learn more about bioeconomy, but also (Section 5 of the questionnaire, not covered here) to have the opportunity to learn about it via a problemoriented learning that combines basic theoretical concepts acquired during courses with more practical and professional life-oriented approaches.

Few courses dealing with bioeconomy from a socialscientific perspective were identified. This is an important finding, considering that bioeconomy in not purely a techno-scientific or economic concept (Goven and Pavone 2015). In order to understand the complex socio-political phenomena shaping this concept, bioeconomy also has to be taught from a critical, social-scientific perspective. According to Repko et al. (2013) most university programs are I-shaped, i.e. they tend to give students in depth knowledge/expertise within one specific discipline. Bioeconomy is "multidisciplinary in nature and it pushes us to be interdisciplinary in our approach" (Geoghegan-Quinn 2010 , p. 4). This makes it appropriate for favouring $\mathrm{T}$-shaped profiles for graduates, i.e. profiles combining a deep expertise in a certain field, with integrative abilities allowing to move across different disciplines and link with them (Lask et al. 2018). Bioeconomy demands crossfunctional and multidisciplinary knowledge (Hakovirta and Lucia 2019). Considering that forestry is a multidisciplinary domain such a transition should be coherent with its own nature, while at the same time encouraging cooperation with other disciplines and leading towards a better topical integration across BSc and MSc programs. Besides the more "classical" techno-scientific and managementoriented disciplines taught at forestry universities, 
fundamental knowledge of the industrial value chains, harvesting and supply chains, manufacturing, logistics and trade of bio-based products and bioeconomy-related services is needed (Golembiewski et al. 2015; Hakovirta and Lucia 2019). Lastly, contributions from universities are the cornerstone for the necessary innovation in the bioeconomy (van Lancker et al. 2016): bioeconomy education should foster a culture of innovation.

\section{The perceived role of forests}

Forestry students perceive the forest-based sector to currently contribute to a bioeconomy in Europe and at national level, however differences across countries can be identified. FIN and SWE (C1), AUT and GER (C4) and FRA (MSc) (C3) consider that the contribution to the bioeconomy by forests at the national level is higher than their contribution at the European scale, while for all other countries (and in particular for $\mathrm{C} 1$ and $\mathrm{C5}$ ) the opposite situation is observed. Except for $\mathrm{C} 3$, target countries where students declare they are more aware of a bioeconomy, they also perceive bioeconomy is more addressed within their university programs and are more satisfied, are also those where they perceive the forest-based sector to be more important within the national bioeconomy. This reflects the relative importance of the forest sector at national level in terms of its contribution to the gross domestic production (Forest Europe 2015). It is also linked to a prevalently technology-driven and product-oriented view of the $\mathrm{FBB}$, with a primary focus on provisioning services (i.e. biomass production) rather than a FBB interpretation giving emphasis to multiple ecosystem services provided by forests.

The bioeconomy is perceived as an opportunity for the forest sector, rather than a threat. On average respondents agree with the idea that the development of a bioeconomy will favour FM and lead to more SFM. Nevertheless, differences emerge in terms of where this will occur. Respondents from ESP, FRA and ITA expect the bioeconomy will mainly favour FM at the local scale, generating positive impacts also on local communities (e.g. employment opportunities), while others expect the bioeconomy to promote FM in general. AUT and GER (C4) reported some concerns regarding SFM that seem to be consistent with similar considerations related to SFM in a bioeconomy context and existing studies. Stern et al. (2018a) for instance reported respondents from AUT associating bioeconomy with an exploitation of natural resources. The political bioeconomy discourse in the countries that have dedicated bioeconomy strategies is generally dominated by economic goals. In contrast, environmental concerns are only considered to a limited extent (Kleinschmit et al. 2017; Ramicilovic-Suominen and
Pülzl 2018). Forest resources are attributed an essential role in the bioeconomy discourse of North European countries (e.g. FIN and SWE) as compared to bioeconomy policies from others (Kleinschmit et al. 2017). These political discourses are well reflected in the student answers from these countries and may become more relevant when considering the need to reconcile bioeconomy policies-looking at forests mainly as biomass sources-and the newly approved EU Biodiversity strategy to 2030 - that sets targets for more nature conservation-within the framework of the EU Green Deal.

\section{Routes to bioeconomy development}

By comparing survey results and clustering to existing literature, different FBB development routes can be identified. Although many nuanced situations can be observed, both across and within countries, a continuum of different visions and transition paths (TP) appears (Table 3). Bioeconomy perception by forestry students within $\mathrm{C} 1$ (in particular FIN and SWE) partly overlaps with the "Life science vision" described in Levidow et al. (2013) and Vivien et al. (2019) and falls between the "sustainable capital" (Birch et al. 2010) and "planned transition" visions identified by Hausknost et al. (2018) and between the "bio-technology" and the "bio-resource" visions reported in Bugge et al. (2016). It can be described as a technology-led shift to bio-innovations, following a linear innovation approach (Rametsteiner and Weiss 2006; Hansen et al. 2011), where the ecologically sustainable use of resources is achieved via advanced (bio)technologies applied at (large scale) industrial level (Hausknost et al., 2018). Such a perspective seems quite in line with the dominant paradigm according to which forest bioeconomy and its innovations in Europe are mainly technologically oriented (Lovrić et al. 2018) and industry dominated (Schmid et al. 2012). The key-driving force at play is decarbonisation with economic growth and competitiveness among the main aims. The prevalent TPs towards a bioeconomy are those of substitution and productivity increase, followed by efficiency increase (Dietz et al. 2018). This position reflects ideas behind the corresponding bioeconomy national strategies and their development approaches (Staffas et al. 2013; Dubois and Gomez San Juan 2016; Pülzl et al. 2017; Hausknost et al. 2018). As regards C4 (in particular AUT and GER), although biobased production and technology remain paramount, the focus is on efficiency that, within a FBB perspective, is translated into sustainable intensification (Godfray et al. 2010), cascading approach (Keegan et al. 2013), woodwaste reduction and circularity. Efficiency and productivity increase are therefore the main TP, while a shift in visions towards in-between bio-resource/bio-technology (Bugge 
et al. 2016), sustainable capital/eco-growth (Hausknost et al., 2018) and type II and III visions (i.e. science-based and biomass-based economy) (Vivien et al. 2019) positions is observed among the respondents' answers to the survey. Research and development, knowledge, and technology are relevant factors at play, and linear innovation remains the main paradigm, however the focus is not just on bio-based products and some attention is paid to a broader range of forest ecosystem services.

C2 and C5 (in particular ITA and ESP, and, to a lower extent, FRA) tend to emphasize bioeconomy components associated to ecosystem services rather than being just bioproduct and technology focused. This perception has some affinity with the bio-ecology vision offered by Bugge et al. (2016), the eco-retreat vision by Hausknost et al. (2018) and type I vision (i.e. ecological economy) by Vivien et al. (2019). It suggests moving away from forests being mainly biomass sources to recognizing and mobilizing the "entire spectrum of ecosystem services that Europe's forests can provide for the benefit of Europe's societies" (Winkel 2020 , p. 153). This is connected to the promotion of local FM and rural development opportunities driven by a diversification into higher value-added products and services with territorial identity (Levidow et al. 2013). Value creation is the main TP, followed by an efficiency increase. While this perspective does not imply that bio-products and technology are totally neglected, it suggests moving away from a purely linear technological innovation into a more complex, non-linear innovation process that involves several interactions among different sectors and actors (Rametsteiner and Weiss 2006; Secco et al. 2018).

\section{CONCLUSIONS}

By combining data collection via an explorative survey, descriptive statistics, cluster analysis and discussion vis-àvis existing literature, this paper presented key findings of a study investigating bioeconomy perceptions by forestry students across Europe. These new insights helped us gain a better understanding of forestry students' perceptions of bioeconomy which may ultimately aid the future development of HEI programs in forestry and serve as important reference for evidence-based educational policies in the future.

The research identified two main perception axes: a major geographical (South-North) and a minor student career (BSc-MSc) axis along which gradients of many surveyed perceptions can be located.

The student career axis seems to be particularly relevant with reference to whether respondents have heard about bioeconomy and perceptions regarding how bioeconomy is currently addressed within university programs. The small sample size of $\mathrm{PhD}$ students and the fact that they are mainly concentrated in one country (GER) do not allow drawing general conclusion for this category.

Along the geographical axis, different perceptions are detected with reference to the importance of the forestry sector. The findings show that there are different visions, understandings as well as degrees of maturity and development of the concept as perceived by forestry students and this implies also different development routes towards the transition to a bioeconomy in European countries. The complexity of such a concept, as well as the debates and controversies in scientific discourses about it imply that universities must reflect their position within the societal transformation process, taking into account both the specificities of the national/local environmental and socioeconomic contexts and global challenges as well as trends. This seems to suggest a combination of measures that call for integrated viewpoints especially across life science universities, but also outside as bioeconomy strategies are so-called integrated strategies that are important for everyone. However, integration does not stand in for harmonization, but rather for a cooperative approach. This should start by engaging and creating awareness: since only one-fourth of respondents are aware of EU/national bioeconomy strategies, this awareness and knowledge gap should be filled. Measures could start providing basic information and a general framework, directions and aims for a bioeconomy development. Questions arise regarding not only the capacity to reach out to future stakeholders, during the development of policy strategies, but also after their publication. Failing to effectively engage future stakeholders at this stage and in communicating and creating awareness might nourish conflicts for the future development of a bioeconomy. Integration should also be sought within and across HEI, as well as between HEI and the "outside world". Integration within HEI should foster interdisciplinarity within programs, bridging BSc and MSc curricula where large gaps have been identified with regard to bioeconomy teaching (e.g. ITA, FRA and ESP) and filling the perceived gap in policy courses dealing with bioeconomy. Students could be given a broader interdisciplinary perspective of the bioeconomy concept first and then be allowed to choose on which aspects to focus on.

Integration across HEI may help coordinating how bioeconomy is addressed in different countries and favour the exchange of different perspectives and approaches to this concept. This could be done both within the same cluster, i.e. involving HEI that supposedly share similar visions and approaches, to help cooperation and advance research and knowledge, and across different clusters, to support spreading of different views and bioeconomy development paths. Recently created programs and university consortia focused on bioeconomy, as well as more 
traditional student exchange programs might serve this purpose and could be integrated with other initiatives spanning from education (including online and blended courses on specific bioeconomy-related topics) to crossboundary research projects (Lovrić et al. 2020).

Finally, integration of HEI and the "world outside" would require reinforcing the role of the "third mission" in universities, i.e. the generation and transfer of knowledge outside the academia by strengthening dialogue and interaction among university and non-university actors. This could help actively engaging future bioeconomy stakeholders within the debate and challenge them with realworld problems while at the same time integrating HEI programs.

How to practically develop the above-reported integration options and the extent to which they can contribute improving HEI programs addressing bioeconomy, however, needs to be further explored.

Despite our efforts to cover perceptions from different European regions, this study is far from exhaustive. The uneven country samples, and the selection of (mainly) one university within each country represent two limiting research aspects that might be integrated in future research activities, although we are aware that enlarging the study scope would be resource intensive. Possible additional research might include running similar surveys within students attending different programs (e.g. in agriculture, economics, energy engineering, materials engineering etc.) at targeted universities/countries, to compare views and perceptions form different domains. The questionnaire might be revised and shortened, thus reducing fatiguing effects reported by some of the respondents.

This study has shed light on how European forestry students perceive the bioeconomy and their expectations from its development. It has shown that perceptions vary across European regions and that much work remains to be done in terms of synchronizing educational efforts and for adapting the curricula for the growing demand for crossfunctional and interdisciplinary bioeconomy education.

\begin{abstract}
Acknowledgements Open access funding provided by Università degli Studi di Padova within the CRUI-CARE Agreement. We are grateful to the European Forest Institute (EFI) for their support to this research via the Network Fund. Our gratitude goes to all people who supported our study by providing input and feedback to the questionnaire as well as by taking their time to circulate, distribute, support and fill in the questionnaire itself. We are also grateful to the anonymous reviewers for their valuable feedback and suggested changes that helped us improving the paper.
\end{abstract}

Open Access This article is licensed under a Creative Commons Attribution 4.0 International License, which permits use, sharing, adaptation, distribution and reproduction in any medium or format, as long as you give appropriate credit to the original author(s) and the source, provide a link to the Creative Commons licence, and indicate if changes were made. The images or other third party material in this article are included in the article's Creative Commons licence, unless indicated otherwise in a credit line to the material. If material is not included in the article's Creative Commons licence and your intended use is not permitted by statutory regulation or exceeds the permitted use, you will need to obtain permission directly from the copyright holder. To view a copy of this licence, visit http://creativecommons. org/licenses/by/4.0/.

\section{REFERENCES}

Bauer, F. 2018. Narratives of biorefinery innovation for the bioeconomy-conflict, consensus or confusion? Environmental Innovation and Societal Transitions 28: 96-107. https://doi.org/10. 1016/j.eist.2018.01.005.

Birch, K., L. Levidow, and T. Papaioannou. 2010. Sustainable capital? The neoliberalization of nature and knowledge in the European "knowledge-based bio-economy". Sustainability 2: 2898-2918. https://doi.org/10.3390/su2092898.

Bugge, M.M., T. Hansen, and A. Klitkou. 2016. What is the bioeconomy? A review of the literature. Sustainability. https:// doi.org/10.3390/su8070691.

D’Amato, D., N. Droste, M. Allen, K. Kettunen, J. Lähtinen, P. Korhonen, B.D. Leskinen, Matthies, and A. Toppinen. 2017. Green, circular, bio economy: A comparative analysis of sustainability avenues. Journal of Cleaner Production 168: 716-734. https://doi.org/10.1016/j.jclepro.2017.09.053.

Drejerska, N. 2017. Employment in vs. education for the bioeconomy. In: Proceedings of the 8th International Scientific Conference Rural Development 2017, ed. A., Raupelienè. https://doi.org/10. 15544/RD.2017.245.

Delvenne, P., and D. Hendrickx. 2013. The multifaceted struggle for power in the bioeconomy. Technology in Society 35: 75-78. https://doi.org/10.1016/j.techsoc.2013.01.001.

Dietz, T., J. Börner, J.J. Förster, and J. von Braun. 2018. Governance of the bioeconomy: A global comparative study of national bioeconomy strategies. Sustainability. https://doi.org/10.3390/ su10093190.

Dubois, O., and M. Gomez San Juan. 2016. How sustainability is addressed in official bioeconomy strategies at international, national and regional levels: An overview. Rome: Food and Agriculture Organization of the United Nations.

Duck, S., and D.T. McMahan. 2017. Communication in everyday life. Singapore: Sage Publications.

EC (European Commission). 2012. Innovating for Sustainable Growth: A Bioeconomy for Europe. Retrieved 23 May, 2020, from https://publications.europa.eu/en/publication-detail/-/ publication/1f0d8515-8dc0-4435-ba53-9570e47dbd51.

EC (European Commission). 2018. A sustainable bioeconomy for Europe: Strengthening the connection between economy, society and the environment. Updated Bioeconomy Strategy. Retrieved 23 May, 2020, from https://publications.europa.eu/en/ publication-detail/-/publication/edace3e3-e189-11e8-b69001aa75ed71a1.

EC (European Commission). 2019. Estimating jobs and wealth in the Bioeconomy. Retrieved 23 May, 2020, from https://ec.europa.eu/ jrc/en/publication/brochures-leaflets/estimating-jobs-and-wealthbioeconomy.

Europe, Forest. 2015. State of Europe's forests 2015. Madrid: Forest Europe.

Geoghegan-Quinn, M. 2010. Bioeconomy for a better life. Opening speech at the conference: The knowledge-based bio-economy towards 2020. SPEECH/10/423. Brussels, 14th November 2010. 
Retrieved 23 May, 2020, from https://europa.eu/rapid/pressrelease_SPEECH-10-423_en.htm.

Godfray, H., J.R. Beddington, I.R. Crute, L. Haddad, D. Lawrence, J.F. Muir, J. Pretty, S. Robinson, et al. 2010. Food security: The challenge of feeding 9 billion people. Science 327: 812-818. https://doi.org/10.1126/science.1185383.

Golembiewski, B., N. Sick, and S. Bröring. 2015. The emerging research landscape on bioeconomy: What has been done so far and what is essential from a technology and innovation management perspective? Innovative Food Science and Emerging Technologies 29: 308-317. https://doi.org/10.1016/j.ifset. 2015.03.006.

Golowko, N., K. Marquardt, S. Budz, and U. Foerster-Metz. 2019. German students' perception of bioeconomy: An exploratory study. Amfiteatru Economic 21: 138-151.

Goven, J., and P. Pavone. 2015. The bioeconomy as political project: A polanyian analysis. Science, Technology and Human Values 40: 302-337. https://doi.org/10.1177/0162243914552133.

Hakovirta, M., and L. Lucia. 2019. Informal STEM education will accelerate the bioeconomy. Nature Biotechnology 37: 103-104. https://doi.org/10.1038/nbt.4331.

Hansen, T., and L. Winther. 2011. Innovation, regional development and relations between high- and low-tech industries. European Urban and Regional Studies 18: 321-339. https://doi.org/10. 1177/0969776411403990.

Hausknost, D., E. Schriefl, C. Lauk, and G. Kalt. 2017. A transition to which bioeconomy? An exploration of diverging techno-political choices. Sustainability. https://doi.org/10.3390/su9040669.

Hempel, C., W. Sabine, and K. Zander. 2018. Societal perspectives on a bio-economy in Germany: An explorative study using Q methodology. Proceedings in System Dynamics and Innovation in Food Networks 2018: 241-260. https://doi.org/10.18461/pfsd. 2018.1818

Herget, J. 2018. The triptych excellence model - fundamentals, concept and implementation. In Unternehmenskultur in der Praxis, ed. J. Herget and H. Strobl, 145-156. Wiesbaden: Springer Gabler. (in German).

Hodge, D., V. Brukas, and A. Giurca. 2017. Forests in a bioeconomy: Bridge, boundary or divide? Scandinavian Journal of Forest Research 32: 582-587. https://doi.org/10.1080/02827581.2017. 1315833.

Hurmekoski, E., M. Lovrić, N. Lovrić, L. Hetemäki, and G. Winkel. 2019. Frontiers of the forest-based bioeconomy: A European Delphi study. Forest Policy and Economics 102: 86-99. https:// doi.org/10.1016/j.forpol.2019.03.008.

James, G., D. Witten, T. Hastie, and R. Tibshirani. 2013. An Introduction to Statistical Learning with applications in $R$. New York: Springer.

Keegan, D., B. Kretschmer, B. Elbersen, and C. Panoutsou. 2013. Cascading use: A systematic approach to biomass beyond the energy sector. Biofuels, Bioproducts and Biorefining 7: 193-206. https://doi.org/10.1002/bbb.1351.

Kleinschmit, D., B.H. Lindstad, B.J. Thorsen, A. Toppinen, A. Roos, and S. Baardsen. 2014. Shades of green: A social scientific view on bioeconomy in the forest sector. Scandinavian Journal of Forestry 29: 402-410. https://doi.org/10.1080/02827581.2014. 921722 .

Kleinschmit, D., B. Arts, I. Giurca, A. Mustalahti, A. Sergent, and H. Pülzl. 2017. Environmental concerns in political bioeconomy discourses. International Forestry Review 19: 1-14. https://doi. org/10.1505/14554817822407420.

Lask, J., J. Maier, B. Tchouga, and R. Vargas-Carpintero. 2018. The bioeconomist. In Bioeconomy, shaping the transition to a sustainable, biobased economy, ed. I. Lewandowski, 343-356. Cham: Springer.
Lewandowski, I. (ed.). 2018. Bioeconomy, shaping the transition to a sustainable, biobased economy. Cham: Springer.

Levidow, L., K. Birch, and T. Papaioannou. 2013. Divergent paradigms of European agro-food innovation: The knowledge based bio-economy (KBBE) as an R\&D agenda. Science, Technology and Human Values 38: 94-125. https://doi.org/10. 1177/0162243912438143.

Lovrić, M., N., Lovrić, and R., Mavsar. 2018. Synthesis on Forest Bioeconomy Research and Innovation in Europe. European Forest Institute, SCAR SWG FOREST. Funded through CASA (Common Agricultural and wider bioeconomy reSearch Agenda) project. Retrieved 23 May, 2020, from https://scareurope.org/ images/FOREST/Documents/SWG_forestry_study.pdf.

Lovrić, M., N. Lovrić, and R. Mavsar. 2020. Mapping forest-based bioeconomy research in Europe. Forest Policy and Economics 110: 101874. https://doi.org/10.1016/j.forpol.2019.01.019.

Mastalka, M., and L., Timonen. 2017. Perspectives on bioeconomy. Cases from the ERDI Partner Regions. ERDI - Empowering Regional Development and Innovations - project, Karelia UAS, University of Pardubice. Retrieved 23 May, 2020, from www. theseus.fi/bitstream/handle/10024/136189/Erdi_report. pdf? sequence $=1 \&$ is Allowed $=y$.

Mustalahti, I. 2017. The responsive bioeconomy: The need for inclusion of citizens and environmental capability in the forest based bioeconomy. Journal of Cleaner Production 30: 1-10.

Pätäri, S., H. Arminen, K. Puumalainen, A. Toppinen, and L. Albareda. 2017. Student values and perceptions of corporate social responsibility in the forest industry on the road to a bioeconomy. Forest Policy and Economics 85: 201-215. https:// doi.org/10.1016/j.forpol.2017.10.009.

Pfau, S.F., J.E. Hagens, B. Dankbaar, and A.J.M. Smits. 2014. visions of sustainability in bioeconomy research. Sustainability 6: 1222-1249. https://doi.org/10.3390/su6031222.

Philippidis, G., R. M'barek, and E. Ferrari. 2016. Is 'Bio-Based' activity a panacea for sustainable competitive growth? Energies 9: 806. https://doi.org/10.3390/en9100806.

Pülzl, H., D. Kleinschmit, and B. Arts. 2014. Bioeconomy: An emerging meta-discourse affecting forest discourses? Scandinavian Journal of Forest Research 29: 386-393. https://doi.org/10. 1080/02827581.2014.920044.

Pülzl, H., A., Giurca, D., Kleinschmit, B., Arts, I., Mustalahti, A., Sergent, L., Secco, D., Pettenella, et al. 2017. The role of forests in bioeconomy strategies at the domestic and EU level. In Towards a sustainable European forest-based bioeconomy assessment and the way forward. What Science Can Tell Us, 8. Joensu: European Forest Institute. Retrieved 23 May, 2020, from www.efi.int/sites/default/files/files/publication-bank/2018/efi_ wsctu8_2017.pdf.

Purdy, M. 1997. What is listening? In Listening in everyday life: A personal and professional approach, ed. M. Purdy and D. Borisoff, 1-20. Lanham, MD: University Press of America.

Ramcilovic-Suominen, S., and H. Pülzl. 2018. Sustainable development: A 'selling point' of the emerging EU bioeconomy policy framework? Journal of Cleaner Production 172: 4170-4780. https://doi.org/10.1016/j.jclepro.2016.12.157.

Rametsteiner, E., and G. Weiss. 2006. Innovation and innovation policy in forestry: Linking innovation process with systems models. Forest Policy and Economics 8: 691-703. https://doi. org/10.1016/j.forpol.2005.06.009.

Ranacher, L., K. Lähtinen, E. Järvinen, and A. Toppinen. 2017. Perceptions of the general public on forest sector responsibility: A survey related to ecosystem services and forest sector business impacts in four European countries. Forest Policy and Economics 78: 180-189. https://doi.org/10.1016/j.forpol.2017.01. 016. 
Repko, A.F., R. Szostak, and M.P. Buchenberger. 2013. Introduction to interdisciplinary studies. Thousand Oaks: Sage.

Sanz-Hernández, A., E. Encarna, and P. Garrido. 2019. Transition to a bioeconomy: Perspectives from social sciences. Journal of Cleaner Production 224: 107-119. https://doi.org/10.1016/j. jclepro.2019.03.168.

Scarlat, N., J. Dallemand, F. Monforti-Ferrario, and N. Nita. 2015. The role of biomass and bioenergy in a future bioeconomy: Policies and facts. Environmental Development 15: 3-34.

Schmid, O., S. Padel, and L. Levidow. 2012. The bio-economy concept and knowledge base in a public goods and farmer perspective. Bio-Based and Applied Economics 1: 47-63.

Secco, L., E. Pisani, M. Masiero, and D. Pettenella. 2018. Social and technological innovation in forestry. In Forestry in the midst of global changes, ed. E. Farcy, I. Rojas-Briales, and M. de Arano, 317-345. Boca Raton: CRC Press.

Staffas, L., M. Gustavsonn, and K. McKormick. 2013. Strategies and policies for the bioeconomy and bio-based economy: An analysis of official national approaches. Sustainability 5: 2751-2769.

Stein, M., A. Giurca, and D. Kleinschmit. 2018. "We are the bioeconomy": Perspectives of actors from the German forestry and timber sector. Allgemeine Forst und Jagdzeitung 189: 30-40. (in German).

Stern, T., U. Ploll, R. Spies, R. Schwarzbauer, R. Hesser, and L. Ranacher. 2018a. Understanding perceptions of the bioeconomy in Austria: An explorative case study. Sustainability.. https://doi. org/10.3390/su10114142.

Stern, T., L. Ranacher, C. Mair, S. Berghäll, K. Lähtinen, M. Forsblom, and A. Toppinen. 2018b. Perceptions on the importance of forest sector innovations: Biofuels, biomaterials, or niche products? Forests 9: 15. https://doi.org/10.3390/f9050255.

Tibshirani, R., T. Walther, and T. Hastie. 2001. Estimating the number of clusters in a data set via the gap statistic. Journal of the Royal Statistical Society: Series B (Statistical Methodology) 63: 411-423.

UNECE/FAO. 2018. Green jobs in the forest sector. Geneva: United Nations Economic Commission for Europe. Retrieved 23 May, 2020, from: www.unece.org/fileadmin/DAM/timber/ publications/DP71_WEB.pdf.

van Lancker, J., E. Wauters, and G. van Huylenbroeck. 2016. Managing innovation in the bioeconomy: An open innovation perspective. Biomass and Bioenergy 90: 60-69. https://doi.org/ 10.1016/j.biombioe.2016.03.017.

Vivien, F.D., M. Nieddu, N. Befort, R. Debref, and M. Giampietro. 2019. The hijacking of the bioeconomy. Ecological Economics 159: 189-197. https://doi.org/10.1016/j.ecolecon.2019.01.027.

Winkel, G. (ed.). Towards a sustainable European forest-based bioeconomy: Assessment and the way forward. What Science Can Tell Us, 8. Joensu: European Forest Institute. Retrieved 23 May, 2020, from www.efi.int/sites/default/files/files/publicationbank/2018/efi_wsctu8_2017.pdf.

Ward, J.H. 1963. Hierarchical grouping to optimize an objective function. Journal of the American Statistics Association 58: 236-244.

Wolfslehner, B., S., Linser, H., Pülzl, A., Bastrup-Birk, A., Camia, and M., Marchetti. 2016. Forest bioeconomy: A new scope for sustainability indicators. From Science to Policy, 4. Joensu: European Forest Institute. https://doi.org/10.36333/fs04.

Publisher's Note Springer Nature remains neutral with regard to jurisdictional claims in published maps and institutional affiliations.

\section{AUTHOR BIOGRAPHIES}

Mauro Masiero $(\square)$ is an Assistant Professor at the Department of Land, Environment, Agriculture and Forestry of the University of Padova (Italy). His research interests include forest policy and economics.

Address: Department of Land, Environment, Agriculture and Forestry, University of Padova, Viale dell Università, 1635020 Legnaro, PD, Italy.

e-mail: mauro.masiero@unipd.it

Laura Secco is an Associate Professor at the Department of Land, Environment, Agriculture and Forestry of the University of Padova (Italy). Her research interests include forest policy and governance. Address: Department of Land, Environment, Agriculture and Forestry, University of Padova, Viale dell Università, 1635020 Legnaro, PD, Italy.

e-mail: laura.secco@unipd.it

Davide Pettenella is a Full Professor at the Department of Land, Environment, Agriculture and Forestry of the University of Padova (Italy). His research interests include forest policy and economics. Address: Department of Land, Environment, Agriculture and Forestry, University of Padova, Viale dell Università, 1635020 Legnaro, PD, Italy.

e-mail: davide.pettenella@unipd.it

Riccardo Da Re is a Post-doc Researcher at the Department of Land, Environment, Agriculture and Forestry of the University of Padova (Italy). His research interests include forest policy and governance. Address: Department of Land, Environment, Agriculture and Forestry, University of Padova, Viale dell Università, 1635020 Legnaro, PD, Italy.

e-mail: riccardo.dare@unipd.it

Hanna Bernö is a M.Sc. student in Forest Sciences at the Swedish University of Agricultural Sciences in Uppsala (Sweden).

Address: Swedish University of Agricultural Sciences, Ulls väg 27, 75651 Uppsala, Sweden.

e-mail: hano0003@stud.slu.se

Ariane Carreira is a Researcher at the National Research Institute of Science and Technology for Environment and Agriculture (Irstea) in Bordeaux (France). Her research focuses on institutional innovation for forest-based bioeconomy.

Address: National Research Institute of Science and Technology for Environment and Agriculture, 50 Avenue de Verdun, 33612 Bordeaux, Cestas, France.

e-mail: ariane.carreira@irstea.fr

Alexander Dobrovolsky is Professor of Forest Policy at the St. Petersburg Forest Technical University (Russia).

Address: Saint-Petersburg State Forest Technical University, Institutskiy per 5, Saint-Petersburg, Russian Federation 194021.

e-mail: alexander-83@yandex.ru

Blanka Giertlieova is an Assistant Professor at the Faculty of Forestry, Technical University in Zvolen (Slovakia). The focus of her current research is on economics and management of natural resources with a special attention on forestry and forest ecosystem services. 
Address: Department of Economics and Management of Forestry, Faculty of Forestry, Technical University in Zvolen, T. G. Masaryka 24, 96001 Zvolen, Slovakia.

e-mail: blanka.giertliova@tuzvo.sk

Alexandru Giurca is a Research Associate at the Chair of Forest and Environmental Policy, University of Freiburg (Germany). His research interests are in the area of forest and environmental policy, with specific focus on bioeconomy developments in Europe and beyond.

Address: Chair of Forest and Environmental Policy, University of Freiburg, Tennenbacherstr. 4, 79106 Freiburg, Germany.

e-mail: alex.giurca@ifp.uni-freiburg.de

Sara Holmgren is a Researcher at the Swedish University of Agricultural Sciences in Uppsala (Sweden). Her research interest includes issues of meaning making, power and participation in forest and environmental governance, with focus on bioeconomy transformation.

Address: Swedish University of Agricultural Sciences, Ulls väg 27, 75651 Uppsala, Sweden.

e-mail: sara.holmgren@slu.se

Cecilia Mark-Herbert is an Associate Professor at at the Swedish University of Agricultural Sciences in Uppsala (Sweden). Her research activities focus on marketing and environmental management aimed at Corporate Responsibility with particular interest in food and fiber-related issues.

Address: Swedish University of Agricultural Sciences, Ulls väg 27, 75651 Uppsala, Sweden.

e-mail: cecilia.mark-herbert@slu.se

Lenka Navrátilová is a Ph.D. Student in forest ecosystem services study programme at the Faculty of Forestry of the Technical University in Zvolen (Slovakia). Her focus is aimed at perception of forest-based bioeconomy and forest ecosystem services in Slovakia. Address: Department of Economics and Management of Forestry, Faculty of Forestry, Technical University in Zvolen, T. G. Masaryka 24, 96001 Zvolen, Slovakia.

e-mail: lenka.navratilova@tuzvo.sk

Helga Pülzl is a Senior Scientist at the Institute of Forest, Environmental and Natural Resource Policy of the University of Natural Resources and Life Sciences, Vienna (BOKU) (Austria) and the European Forest Institute Forest Policy Research Network. Her research activities focus on European and international forest policy and social perception in the forest-based sector.

Address: Institute of Forest, Environmental and Natural Resource Policy, University of Natural Resources and Life Sciences (BOKU) in Vienna, Feistmantelstraße 4, 1180 Vienna, Austria.

e-mail: helga.puelzl@boku.ac.at

Lea Ranacher is a Researcher at the Market Analysis \& Innovation Research Team of Wood $\mathrm{K}$ plus. Her research activities focus on market analysis and the social perception of the forest-based sector. Address: Institute of Forest, Environmental and Natural Resource Policy, University of Natural Resources and Life Sciences (BOKU) in Vienna, Feistmantelstraße 4, 1180 Vienna, Austria.

Address: Wood K plus - Competence Center for Wood Composites and Wood Chemistry, Kompetenzzentrum Holz GmbH, Altenberger Straße 69, 4040 Linz, Austria.

e-mail: lea.ranacher@boku.ac.at
Alessandra Salvalaggio is a M.Sc. student in Forest Sciences at the University of Freiburg (Germany).

Address: Chair of Forest and Environmental Policy, University of Freiburg, Tennenbacherstr. 4, 79106 Freiburg, Germany.

e-mail: alessandrasalvalaggio33@gmail.com

Arnaud Sergent is a Senior Researcher at the National Research Institute of Science and Technology for Environment and Agriculture (Irstea) in Bordeaux (France). His research activities focus on forest policy and governance.

Address: National Research Institute of Science and Technology for Environment and Agriculture, 50 Avenue de Verdun, 33612 Bordeaux, Cestas, France.

e-mail: arnaud.sergent@irstea.fr

Juuso Sopanen is a M.Sc. student in Forest Sciences at the University of Helsinki (Finland).

Address: Department of Forest Sciences, University of Helsinki, Latokartanonkaari 7, 00790 Helsinki, Finland.

e-mail: juuso.sopanen@helsinki.fi

Cristoph Stelzer is a M.Sc. student in Forest Sciences at the University of Natural Resources and Life Sciences (BOKU), Vienna (Austria).

Address: Institute of Forest, Environmental and Natural Resource Policy, University of Natural Resources and Life Sciences (BOKU) in Vienna, Feistmantelstraße 4, 1180 Vienna, Austria.

e-mail: christoph.stelzer@students.boku.ac.at

Theresa Stetter is a B.Sc. Student in Forest Sciences at the University of Freiburg (Germany).

Address: Chair of Forest and Environmental Policy, University of Freiburg, Tennenbacherstr. 4, 79106 Freiburg, Germany.

e-mail: theresa.stetter@posteo.de

Lauri Valsta is a Full Professor at the Department of Forest Sciences of the University of Helsinki (Finland). His main research interests are the economics of forest management and climate change mitigation in the forest sector.

Address: Department of Forest Sciences, University of Helsinki, Latokartanonkaari 7, 00790 Helsinki, Finland.

e-mail: lauri.valsta@helsinki.fi

Jozef Výbošt'ok works as Post-doc Researcher at the Technical University in Zvolen (Slovakia). His research interests are focused on fulfilment of forest ecosystem services, mainly on effect of forest management on fulfilment forest ecosystem services.

Address: Department of Economics and Management of Forestry, Faculty of Forestry, Technical University in Zvolen, T. G. Masaryka 24, 96001 Zvolen, Slovakia.

e-mail: jozef.vybostok@tuzvo.sk

Ida Wallin is a Post-doc Researcher at the Chair of Forest and Environmental Policy, University of Freiburg (Germany). Her research interests include stakeholder and public participation in forestry decision-making, and public opinion formation in news and social media.

Address: Chair of Forest and Environmental Policy, University of Freiburg, Tennenbacherstr. 4, 79106 Freiburg, Germany. e-mail: ida.wallin@ifp.uni-freiburg.de 